\title{
The northeastern Chukchi Sea: benthos-environmental interactions
}

\author{
Howard M. Feder ${ }^{1}$, A. Sathy Naidu ${ }^{1}$, Stephen C. Jewett ${ }^{1}{ }^{\text {Jawed M. Hameedi }}{ }^{2}$, \\ Walter R. Johnson ${ }^{3}$, Terry E. Whitledge ${ }^{4}$ \\ ${ }^{1}$ Institute of Marine Science, University of Alaska Fairbanks, Fairbanks, Alaska 99775-7220, USA \\ ${ }^{2}$ NOAA/NOS/ORCA/CMBAD Bioeffects Assessment Branch, 6001 Executive Blvd, Room 323, Rockville, Maryland 20852, USA \\ ${ }^{3}$ MMS/BEOA/TAG, MS4340, 381 Elden Street, Herndon, Virginia 22070, USA \\ ${ }^{4}$ Marine Science Institute, University of Texas at Austin, Port Aransas, Texas 78373, USA
}

\begin{abstract}
Benthic faunal abundance, diversity, and biomass were examined in the northeastern Chukchi Sea to determine factors influencing faunal distribution. Four taxon-abundance-based benthic station groups were identified by cluster analysis and ordination techniques. These groups are explained, using stepwise multiple discriminant analysis, by the gravel-sand-mud and water content of bottom sediments, and the organic carbon/nitrogen $(\mathrm{OC} / \mathrm{N})$ ratio. In contrast to previous benthic investigations in the northeastern Bering and southeastern Chukchi Seas, faunal diversity between inshore and offshore regions in our study area were not related to differences in sediment sorting. Instead, regional diversity differences in the northeastern Chukchi Sea were related to greater environmental stresses (e.g. ice gouging, wave-current action, marine-mammal feeding activities) inshore than offshore. The presence of a high benthic biomass north of lcy Cape in the vicinity of Point Franklin and seaward of a hydrographic front is presumably related to an enhanced local depositional flux of particulate organic carbon (POC) in the area. We postulate that POC-rich waters derived from the northern Bering and northwestern Chukchi Seas extend to our study area and the flux of the entrained POC provides a persistent source of carbon to sustain the high benthic biomass. Annual POC enrichment of the coastal region north of Icy Cape is reflected by the great abundance of amphipods and other invertebrates present there and the concentration in summer of walrus Odobenus rosmarus divergens and gray whales Eschrichtius robustus that feed on these invertebrates. This study demonstrates that there can be high standing stocks of benthos in arctic regions with relatively low annual primary production if local carbon is augmented by POC advected from highly productive areas.
\end{abstract}

KEY WORDS: Benthos - Community structure - Biomass - Bottom front POC advection - Multivariate analysis $\cdot$ Arctic $\cdot$ Chukchi Sea

\section{INTRODUCTION}

The relative importance of environmental factors in shaping benthic systems of continental shelves can vary widely (Coull 1977, Tenore \& Coull 1980, Postma \& Zijlstra 1988). Among the various environmental factors, primary production can have a major shaping role because of its importance in determining the amount of food available to the benthos. In high arctic continental shelves primary production is generally low (Subba Rao \& Platt 1984), and is typically reflected by reduced yearly input of autochthonous particulate organic carbon (POC) to the benthos. This low primary production is a result of extensive yearly sea-ice cover which imposes light limitation, prolonged and strong vertical stability of the water column and low nutrient supply (Dunbar 1968, McRoy \& Goering 1974, Nemoto \& Harrison 1981, Subba Rao \& Platt 1984). Consequently, on those arctic shelves where the supply of POC is low and derived only from local primary production, benthic abundance and biomass are reduced (Thomson 1982, Grebmeier \& Barry 1991). This implies that, in the arctic, for the maintenance of a high benthic abundance and biomass it is essential that an adequate allochthonous source of POC be available. The relationship between benthic abundance and biomass, and differences in the source of POC (both 
allochthonous and autochthonous) is well documented for the northeastern Bering and southeastern Chukchi Seas (Grebmeier et al. 1988). In the adjacent northeastern Chukchi Sea, characterized by considerably lower primary productivity (Parrish 1987), the benthos has not been examined in the context of the source of POC. The transport of nutrients and POC from the Bering Sea to the southeastern Chukchi Sea is described by Walsh et al. $(1989 \mathrm{a}, \mathrm{b})$, but the importance of these advected nutrients and POC to the benthos in the adjacent northeastern Chukchi Sea is not known. Much of the initial pulse of water-column primary productivity on the shallow shelf of most northern Alaskan waters remains ungrazed (Cooney \& Coyle 1982, Walsh \& McRoy 1986, Grebmeier et al. 1988, Dunton et al. 1989, Springer et al. 1989). The sinking of ungrazed phytoplankters, as well as POC advected from more southerly waters, would be expected to enrich the benthic environment of the northeastern Chukchi Sea. This conjecture is supported for the northern portion of the latter area by the presence of high standing stocks of amphipods and mollusks in excess of that to be expected based on local carbon production (Feder et al. 1989, 1994) and the annual return of feeding populations of walrus Odobenus rosmarus divergens and gray whales Eschrichtius robustus (Ingham et al. 1972, Fay 1982, Davis \& Thomson 1984, Clarke et al. 1987, Phillips \& Colgan 1987).

Numerous publications on distribution and biology of the macrobenthos in the northeastern Chukchi Sea are available (e.g. MacGinitie 1955, 1959, Filatova 1957, Sparks \& Pereyra 1966, Ingham et al. 1972, Hoberg et al. 1980, 1982, Phillips \& Reiss 1985a, b, Phillips \& Colgan 1987, Jewett 1988a, b), but only Stoker $(1978,1981)$ and Feder et al. (1994) include quantitative information. The study in the northeastern Chukchi Sea reported here expands a quantitative benthic data base available for the north Bering and contiguous southeast Chukchi Seas and the adjacent Beaufort Sea (Carey et al. 1974, 1984, Stoker 1981, Feder et al. 1985, 1990, Grebmeier et al. 1988, 1989). We examine the distribution and dynamics of lithological and benthic facies, and the relationships of benthos to sediment and water-mass characteristics and marine mammals in the northeastern Chukchi Sea.

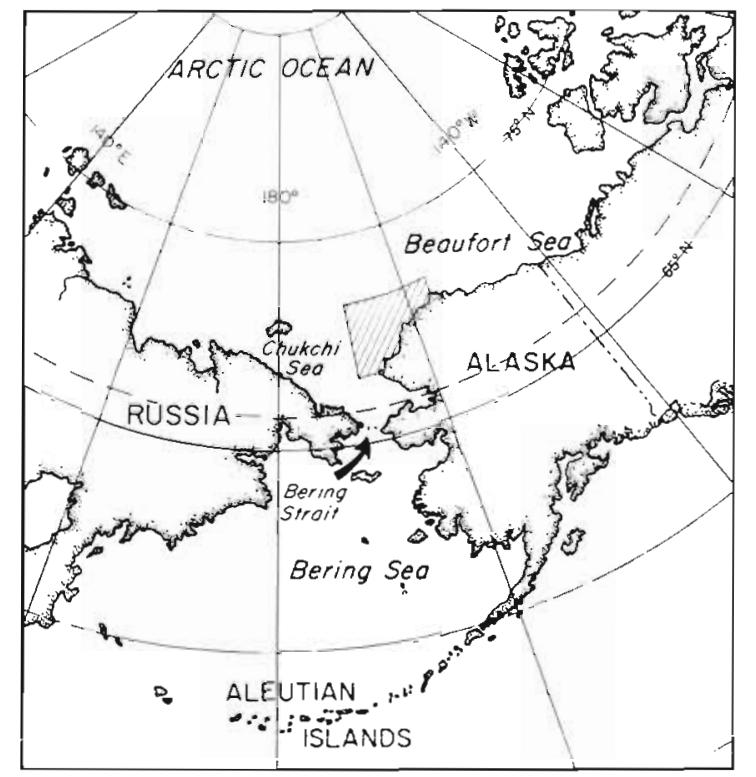

Fig. 1. Location of the study area (cross hatched) (from Feder et al. 1994)

\section{STUDY AREA}

The northeastern Chukchi Sea (Figs. $1 \& 2$ ) is relatively shallow with an average depth of $50 \mathrm{~m}$. Although the bottom is generally smooth, there are several

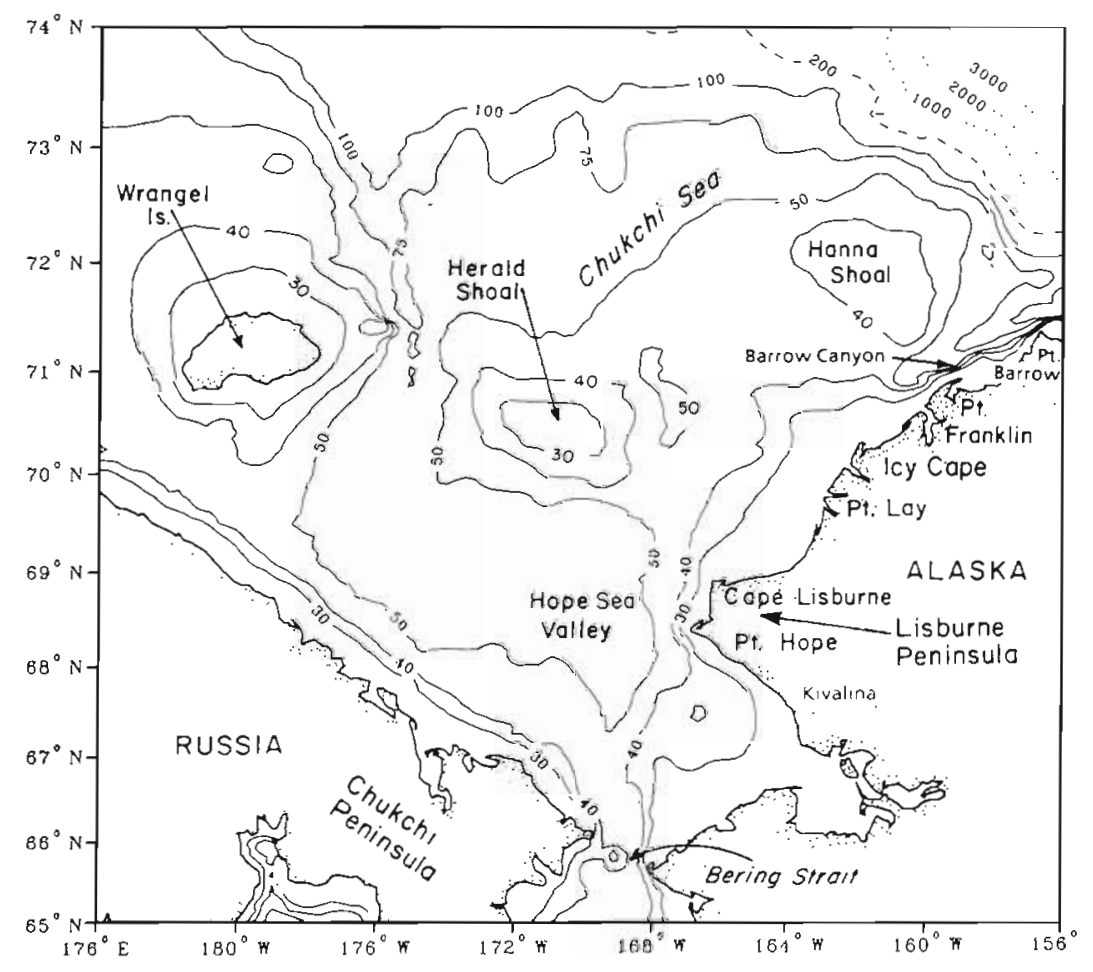

Fig. 2. Bathymetry of the Chukchi Sea (from Feder et al. 1994) 
important bathymetric features which influence the flow and distribution of water masses. Water mass properties of the Chukchi Sea are discussed by Coachman et al. (1975), Johnson (1989), Walsh et al. (1989a, b), and Weingartner (1993, unpubl.). Chukchi Sea waters reflect advective and in situ processes, with the most important of these being the northward advection of waters through Bering Strait. This flow bifurcates offshore of the Lisburne Peninsula. The northwestward branch transports Bering Shelf Water (BSW) through the Hope Sea Valley with a northeastern branch of BSW flowing along the east flank of Herald Shoal (Feder et al. 1994). The BSW entering the Chukchi Sea is characterized by low temperatures $\left(-1\right.$ to $\left.2^{\circ} \mathrm{C}\right)$, high salinity $(>32.5 \%)$ and relatively high nutrient and POC concentrations (Grebmeier et al. 1988, Walsh et al. 1989a, b). In summer and fall, a northeastward-flowing branch forms the Alaska Coastal Current (ACC) which consists primarily of Alaska Coastal Water (ACW). This water mass, which is heavily influenced by the Yukon River and numerous smaller drainages along the Alaskan coast, consists of relatively warm $\left(>2{ }^{\circ} \mathrm{C}\right)$ and less saline $(<31.8 \%$ u) water, with a high sediment load (Burbank 1974), but low concentrations of nutrients and POC (Grebmeier et al. 1988). A third water mass, Resident Chukchi Water (RCW), is either advected onshore from the upper layers of the Arctic Ocean and/or is ACW and BSW remnant from the previous winter. A bottom-intersecting front paralleling the 30 and $40 \mathrm{~m}$ isobaths is typically observed in summer and fall (Johnson 1989, Weingartner 1993). This front extends northward from the Lisburne Peninsula to about $71^{\circ} \mathrm{N}$ and then swerves eastward toward Point Franklin. ACW lies inshore of the front while BSW and RCW lie offshore and to the north of this front. Because $\mathrm{ACW}$ is less dense than BSW or RCW, it may also occur at the surface and offshore of the bottom front. Coachman \& Shigaev (1992) and Whitledge et al. (1992) speculate that a fraction of the water flowing north along the Lisburne Peninsula is ultimately derived from the vicinity of Wrangel Island in the northwest Chukchi Sea. This highsalinity, nutrient-rich water is advected into the southeastern Chukchi Sea by the Siberian Coastal Current. They suggest that nutrients within this current supplement those derived from the Bering Sea to enhance annual primary production in the southcentral Chukchi Sea and contribute POC to the northeastern shelf. Occasionally, upwelling occurs along the northeastern margin of our study area from Icy Cape to Point Barrow (Wiseman \& Rouse 1980, Johnson 1989, Aagard \& Roach 1990) and may also occur at the shelf edge (Weingartner pers. comm.).

All sediments are very poorly to extremely poorly sorted. The inner shelf between Point Hope and Point
Barrow is carpeted by relatively coarse sand and gravel. Further seaward are predominantly muds containing minor proportions of gravel and sand (Naidu 1988). With the exception of a few disjointed polynyas within the inshore region (Stringer \& Groves 1991), the Chukchi Sea shelf is covered with sea ice from November through June (Phillips \& Reiss 1985a, b, Carey 1991).

\section{MATERIALS AND METHODS}

Bottom surficial sediment and macrobenthic samples were collected August to September 1986 with a $0.1 \mathrm{~m}^{2}$ van Veen grab. Station locations were selected on the basis of known variations in sediment types (Naidu 1987), bathymetry (Hill et al. 1984, Phillips \& Reiss $1985 \mathrm{a}, \mathrm{b})$, and mean ice position in summer (Grantz et al. 1982). Depths of stations ranged from 18 to $51 \mathrm{~m}$. For the collection of suspended particles in nearbottom waters, 1 I water samples were retrieved from Niskin bottles attached to a CTD system and programmed to obtain samples at $5 \mathrm{~m}$ from the bottom. Nutrient and dissolved oxygen samples were taken from the water column August 1990.

Bottom sediment samples were collected at 45 stations (Fig. 3), and analyzed for grain size parameters according to Folk (1980). Water content, by weight, in gross sediments was estimated to get a measure of sediment fluidity, an important parameter affecting the benthic habitat (Boswell 1961). One liter of each Niskin water sample was filtered through pre-weighed Nucle-

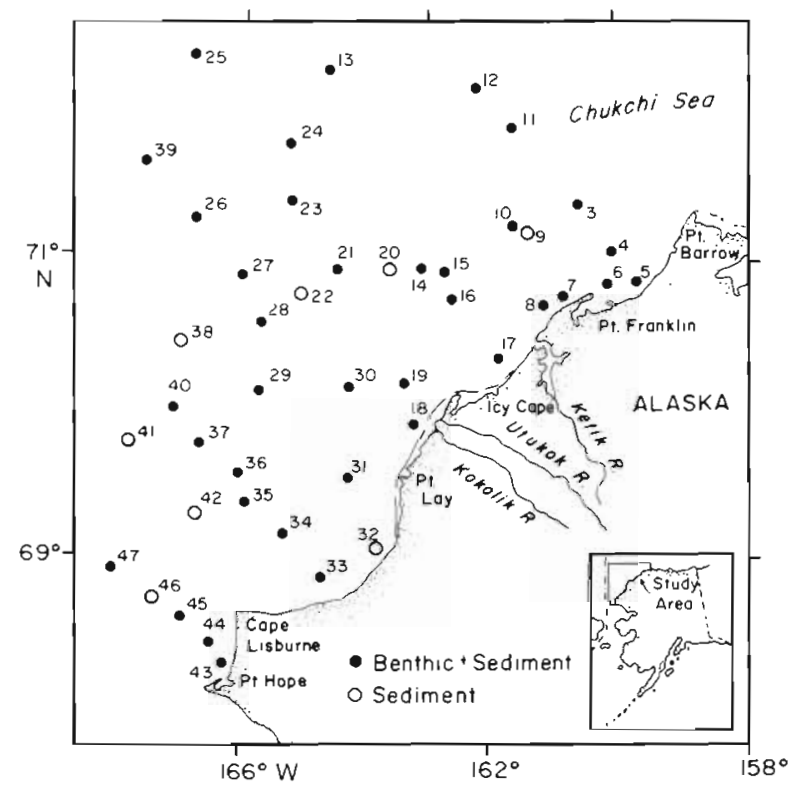

Fig. 3. Station locations in the northeastern Chukchi Sea where geological and biological data were collected 
pore filter membranes (pore size $0.4 \mu \mathrm{m}$ ) for determination of suspended matter. Organic carbon (OC) and nitrogen $(N)$ were analyzed on carbonate-free samples of bottom sediments, using a Perkin-Elmer Model 240B $\mathrm{CHN}$ analyzer. The precision of the $\mathrm{OC}$ and $\mathrm{N}$ analyses was better than $8 \%$. OC/N values were computed on a weight to weight basis.

Nutrient and dissolved oxygen samples were collected in August 1990 at 28 stations with a CTD/rosette sampler at approximately $5 \mathrm{~m}$ intervals throughout the water column. Nutrient samples were analyzed within $1 \mathrm{~h}$ of collection with an Alpkem RFA chemical analyzer using standard analytical methods (Whitledge et al. 1981). Dissolved oxygen concentrations were determined on all samples by standard Winkler titrations.

Five replicate benthic biological samples were collected at 37 selected stations (Fig. 3). Samples were sieved on a $1.0 \mathrm{~mm}$ mesh screen, fixed in $10 \%$ buffered formalin, and animals identified, counted, and wet weighed. As in other benthic biological studies (e.g. Grebmeier et al. 1989), organisms collected by grab, and subsequently used in analyses, included slowmoving surface dwellers and small, sessile epifauna. Highly motile epifauna such as large gastropods, shrimps, crabs and sea stars (except the infaunal sea star Ctenodiscus crispatus) were excluded from analyses. Wet-weight biomass values were converted to organic carbon biomass using previously verified conversion values (Stoker 1978). The carbon conversions permit comparisons of biomass between stations by reducing the influence of calcium carbonate in mollusks and echinoderms on total biomass. A statistical comparison of carbon biomass at stations north and south of the identified bottom front (Johnson 1989) consisted of $t$-tests utilizing SYSTAT (Wilkinson 1990).

Diversity (Shannon: $H^{\prime}$; Shannon \& Weaver 1963) and dominance (Simpson: $D_{i}$ Simpson 1949, Odum 1975) indices, and species richness (Margalef 1958) were calculated. Data used for classification and ordination of stations consisted of taxon abundance values. Station groups were identified by hierarchical cluster analysis. The Czekanowski coefficient was used to calculate similarity matrices for cluster analyses (Bray $\&$ Curtis 1957, Boesch 1977). Since the latter coefficient emphasizes the effect of dominant taxa on classification, logarithmically transformed $[\ln (x+1)]$ data were used. Principal coordinate analysis (Gower 1967, 1969) aided interpretation of the cluster analysis (Stephenson \& Williams 1971, Boesch 1973, Probert \& Wilson 1984). Fauna were categorized by trophic groups according to Jumars \& Fauchald (1977) and Grebmeier et al. (1989). The mean percentage of each trophic group within each station group was calculated. Values for each trophic group were compared by 1-way ANOVA, and multiple comparisons were performed with the
Student-Neuman-Keuls test using a statistical package (SigmaStat; Jandel 1992).

Stepwise multiple discriminant analysis (MDA), using a BMDP7M program, was applied to biological data to correlate station group separation by cluster analysis with environmental variables. Analyses were performed using physical oceanographic variables (salinities and temperatures of surface and bottom waters), sediment variables (sediment water content, size composition, mean size and sorting, organic carbon and nitrogen, and $\mathrm{OC} / \mathrm{N}$ ratio) based on either dry or wet weight determinations. Percentage values for sediment variables were arcsine transformed. Additionally, MDA was performed to correlate regional separation of benthic fauna by biomass with oceanic variables (depth, surface and bottom-water temperature and salinity, and current velocity). MDA has been used elsewhere and in the northeastern Chukchi Sea to test a biological model (e.g. benthic station groups) with environmental parameters (Flint 1981, Shin 1982, Weston 1988, Feder et al. 1994).

\section{RESULTS}

\section{Sediment composition}

Sediments were typically very poorly to extremely poorly sorted (Appendix I). The distributional pattern of sediments closely conformed to that described by Naidu (1988) for the northeastern Chukchi Sea with a trend of seaward fining of sediment types from gravel to muds. However, within broad lithologic units identified, a mosaic of different sediment subtypes occurred. At shoals within the outer shelf (e.g. Hanna and Herald Shoals) erosional lag deposits comprised of poorly sorted gravels occurred surrounded by muds.

The suspended sediment concentrations $5 \mathrm{~m}$ above the sea floor (BWSP) are shown in Appendix I and the distribution depicted in Fig. 4. There is a concentration gradient in the suspended particles within the nearshore region. In the vicinity of Herald and Hanna shoals (see Fig. 2) the concentrations of suspended particles were relatively high. The concentrations of $\mathrm{OC}$ in bottom sediments are shown in Appendix I and their distribution in Fig. 5. Highest concentrations of $\mathrm{OC}$ and $\mathrm{N}$ (Appendix I) occurred at stations northwest of Point Franklin and at 4 stations northwest of Point Hope.

\section{Nutrient and oxygen distribution}

Since carbon derived from primary production originates in the upper water column, the distributional patterns of nutrients and dissolved oxygen can be used 


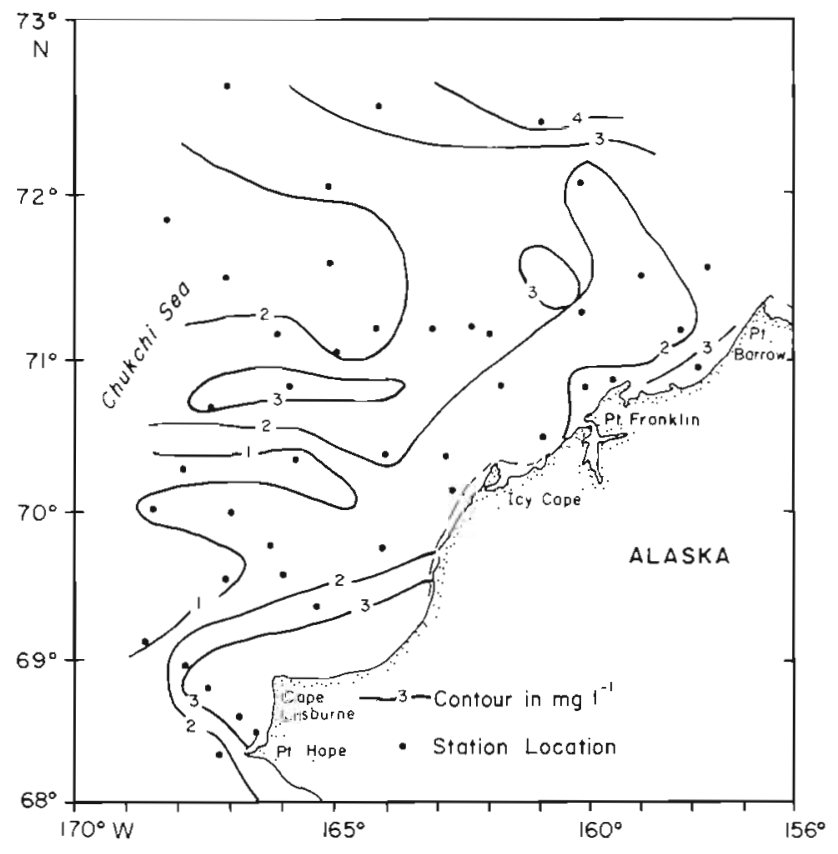

Fig. 4. Suspended sediment particles (in $\mathrm{mg} \mathrm{l}^{-1}$ ) $5 \mathrm{~m}$ above the bottom

as indicators of locations of food production. More than 5 years of nutrient data collected in the Chukchi Sea suggest that $60 \%$ of the nitrate advected from the deep Bering Sea is still available for uptake within the northern Chukchi Sea (Walsh 1989). These relatively high concentrations of nitrate are apparent in the offshore waters north of $71^{\circ}$ (Fig. 6), in contrast to much lower

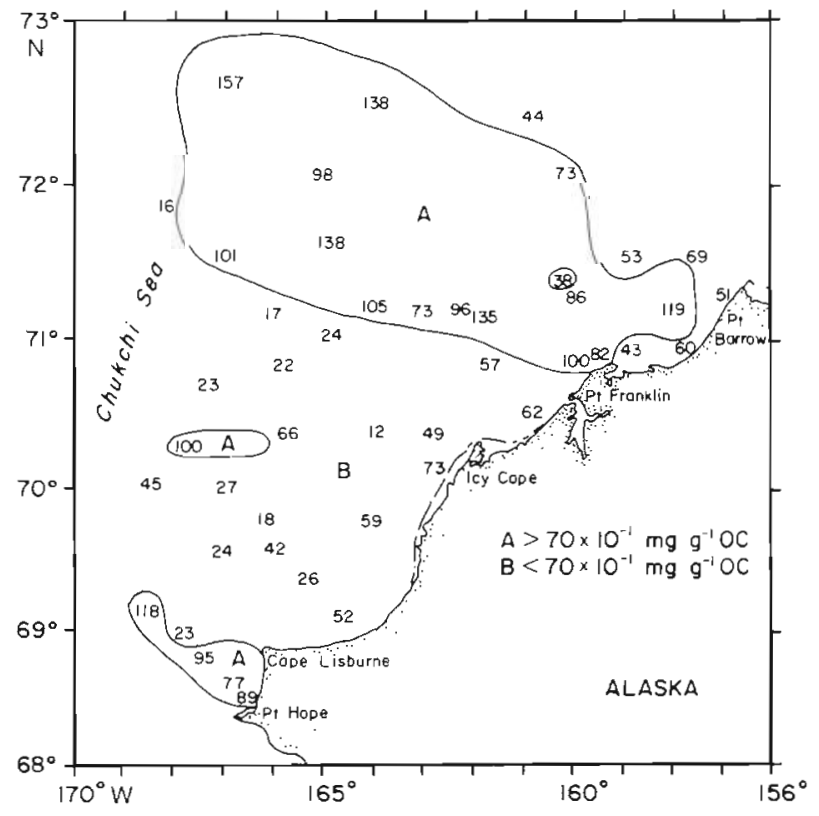

Fig. 5. Organic carbon $\left(\mathrm{mg} \mathrm{g}^{-1}\right)$ in bottom surficial sediments values in the nearshore waters south of $70^{\circ} 30^{\prime}$ (Walsh et al. 1989b). The high nitrate concentrations are associated with mixtures of Bering Shelf Water (BSW) and possible Siberian Coastal Water (Coachman \& Shigaev 1992, Whitledge et al. 1992). A pycnocline at about $25 \mathrm{~m}$ is established in the offshore areas deeper than $30 \mathrm{~m}$, which allows maintenance of relatively high concentrations of nutrients in subpycnocline waters. The subsurface dissolved oxygen concentrations are maximal at the pycnocline and represent an accumulation of oxygen from primary production processes (Fig. 6). There is good correspondence between elevated subsurface nitrate available for phytoplankton growth and supersaturated dissolved oxygen concentrations at the bottom edge of the pycnocline. The highest subsurface oxygen concentrations measured near the pycnocline on the northern transect represent 135 to $145 \%$ saturation. These concentrations correspond well with previous observations (Musina \& Balysheva 1960, Codispoti \& Richards 1971) with reported values of $140 \%$ saturation in the Chukchi and East Siberian Seas.

\section{Benthic fauna}

General. Over 425 taxa were identified with polychaetous annelids, crustaceans (primarily barnacles and amphipods), and mollusks (mainly bivalves) typically dominant in abundance. Sipunculids, bivalves, sea cucumbers, and sand dollars generally dominated biomass (Feder et al. 1989, Feder et al. 1994).

Number of taxa, abundance, and diversity of individual stations. Number of taxa ranged from 23 (inshore Stn $\mathrm{CH} 31$ ) to 143 (inshore Stn $\mathrm{CH} 16$ ) (Appendix II). Abundance varied from 454 ind. $\mathrm{m}^{-2}$ (offshore northern Stn $\mathrm{CH} 13$ ) to 31576 (inshore northern Stn $\mathrm{CH} 16$ ). Highest abundance values generally occurred close to the coast north of Icy Cape in the vicinity of Point Franklin. High Shannon and low Simpson dominance indices were generally present at offshore muddy stations in contrast to relatively low Shannon and high Simpson values at inshore sandy-gravel stations (Fig. 3, Appendix II).

Benthic biomass of individual stations. Carbon biomass varied from 1.0 (inshore Stn $\mathrm{CH} 45$ adjacent to Cape Lisburne) to $19.6 \mathrm{~g} \mathrm{C} \mathrm{m}^{-2}$ (inshore Stn $\mathrm{CH} 7$ adjacent to Point Franklin) (Appendix II). Mean carbon biomass $\left(10.3 \pm 4.3 \mathrm{~g} \mathrm{C} \mathrm{m}^{-2}\right)$ at stations to the north and west of the bottom front identified by Johnson (1989) and Weingartner (1993) was significantly higher $(\mathrm{p}<0.001)$ than that for the southern stations $\left(5.2 \pm 2.3 \mathrm{~g} \mathrm{C} \mathrm{m}^{-2}\right)$ (Fig. 7). Separation of northern and southern groups of stations by biomass was explained by stepwise MDA. Since bottom temperature and bottom salinity were highly correlated variables, 2 sepa- 

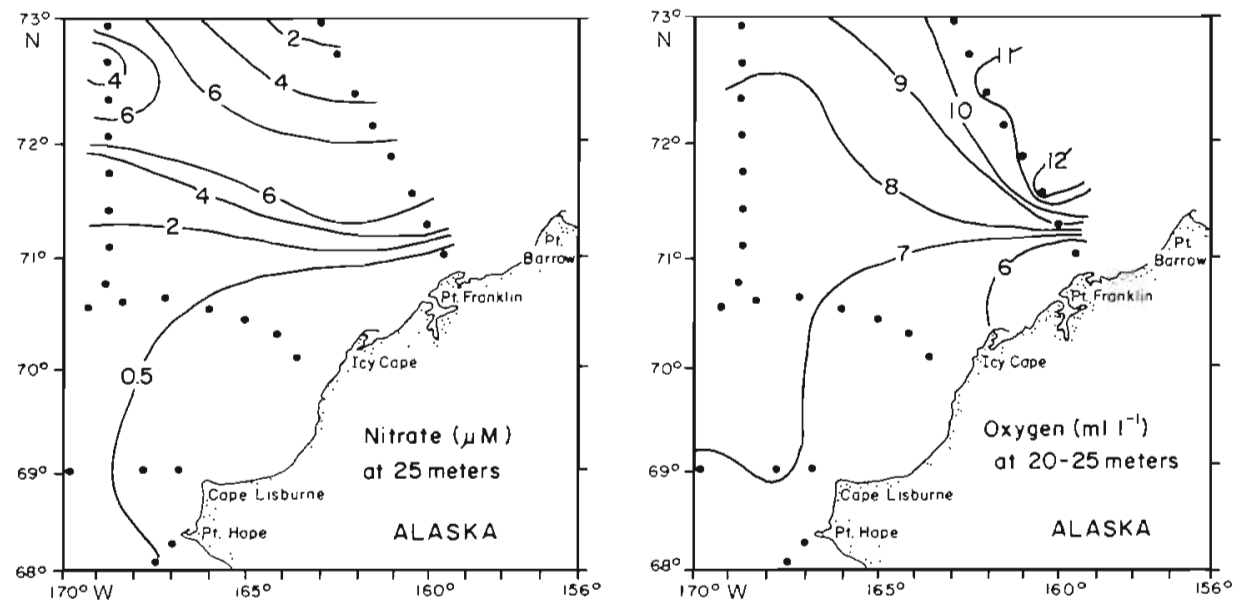

Fig. 6. Subsurface distribution of nitrate $(\mu \mathrm{M})$ and dissolved oxygen $\left(\mathrm{ml} \mathrm{l}^{-1}\right)$ in the northeastern Chukchi Sea in August 1990

rate analyses were run, each with either bottom temperature or bottom sdinity, in addition to other oceanographic variables. Discriminant function 1 for each analysis contributed $100 \%$ of the total separation between the 2 groups. Further, 91.9 to $97.3 \%$ (the former for bottom salinity; the latter for bottom temperature) of the stations were correctly grouped by the jackknife classification into the 2 groups by the variable (either bottom salinity or bottom temperature) that formed a single discriminant function. Thus, the separation of the 2 groups, by carbon biomass, is due to lower bottom-water temperatures and higher bottom salinities in the northern region, values typical of BSW (Waish et al. 1989a, b).

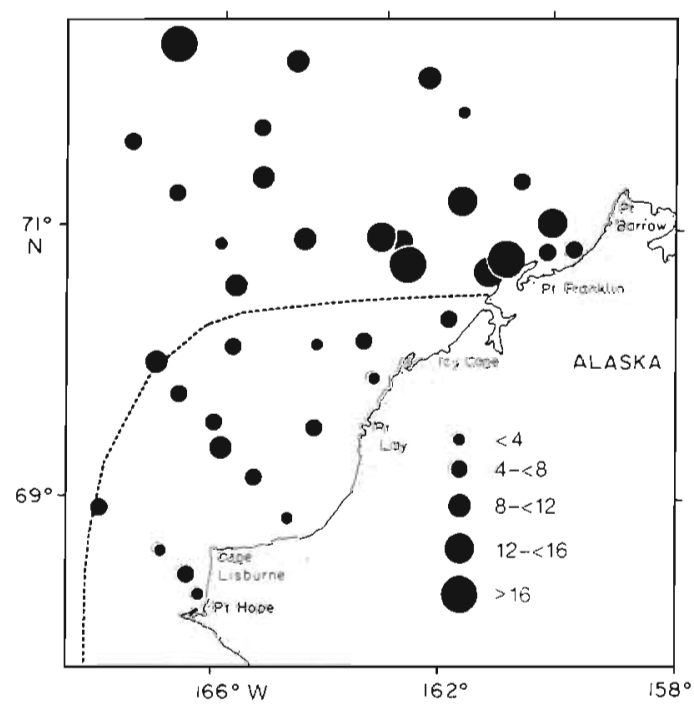

Fig. 7. Distribution of carbon biomass $\left(\mathrm{g} \mathrm{C} \mathrm{m}^{-2}\right)$ in the northeastern Chukchi Sea. Dashed line represents the hydrographic bottom front identified by Johnson (1989) and Weingartner (1993)
Amphipod abundance, biomass and dominant families. Benthic amphipods, a major food for gray whales (Nerini 1984, Highsmith \& Coyle 1992), represented the major faunal component at coastal stations adjacent to and north of the bottom front with abundance and carbon biomass higher ( $p \leq 0.01$ : Mann-Whitney Rank Sum Test) there than to the south. Amphipods at 5 of the coastal stations north of the front (Stns CH5, 6, $7,10 \& 17$ ), within a region identified as a feeding area for gray whales in summer (Phillips \& Reiss 1985a, b, Moore \& Clarke 1992), comprised $65 \%$ of the total infaunal abundance and $37 \%$ of the total carbon biomass (Table 1). Amphipod abundance varied between 1562 and 6644 ind. $\mathrm{m}^{-2}$ at the 5 coastal stations. Dominant amphipod families, by abundance, at the above stations were the Ampeliscidae (a tube dweller), Isaeidae and Atylidae $(30,28$ and $23 \%$ of the amphipod abundance, respectively) and by carbon biomass, Atylidae and Ampeliscidae (66 and $27 \%$, respectively) (Table 2). Ampeliscid amphipods consisted of Ampelisca eschrichti, A. macrocephala and Byblis spp. Isaeid amphipods were dominated by Protomedeia spp. and the tube dweller Photis spp. The important atylid was Atylus bruggeni.

Community structure. Cluster analysis delineated 4 station groups, 2 offshore (I and II) and 2 inshore (III and IV) (Fig. 8). Principal coordinate analysis (PCA) indicated that $70 \%$ of total variation among stations was accounted for by the first 3 coordinates. PCA shows stations of offshore Groups I and II to be relatively well separated on the plot of the first and second coordinate axes (Fig. 9a). Although Stn CH5 is located along the coast and north of other Group I stations, it joins Group I at a relatively high level of similarity in the cluster analysis and is closely associated with Group I on principal coordinate plots. Separation of inshore Groups III and IV is best shown on the plot of the first and second coordinate axes, although Str CH8 
Table 1. Stations in the northeastern Chukchi Sea between Point Hope and Point Barrow within $50 \mathrm{~km}$ of shore. Stations are within the area where gray whales occur during the summer. $\bar{x}=$ mean; SD = standard deviation

\begin{tabular}{|c|c|c|c|c|c|c|}
\hline \multirow[t]{2}{*}{$\operatorname{Stn}$} & \multicolumn{2}{|c|}{ Abundance (ind $\mathrm{m}^{-2}$ ) } & \multirow{2}{*}{$\begin{array}{c}\% \\
\text { Amphipods }\end{array}$} & \multicolumn{2}{|c|}{ Biomass ( $\mathrm{g} \mathrm{C} \mathrm{m}^{-2}$ ) } & \multirow{2}{*}{$\begin{array}{c}\% \\
\text { Amphipods }\end{array}$} \\
\hline & All infauna & Amphipods & & All infauna & Amphipods & \\
\hline $\mathrm{CH} 5$ & 3656 & 2302 & 63.0 & 6.63 & 0.81 & 12.2 \\
\hline $\mathrm{CH} 6$ & 8472 & 6644 & 78.4 & 5.62 & 2.90 & 51.6 \\
\hline $\mathrm{CH} 7$ & 7482 & 5204 & 69.6 & 19.64 & 13.50 & 68.7 \\
\hline $\mathrm{CH} 10$ & 2912 & 1562 & 53.6 & 13.0 & 3.13 & 24.0 \\
\hline $\mathrm{CH} 17$ & 4998 & 3128 & 62.6 & 6.64 & 1.82 & 27.4 \\
\hline $\begin{array}{l}\bar{x} \\
(\mathrm{SD})\end{array}$ & $\begin{array}{c}5504 \\
(2403)\end{array}$ & $\begin{array}{l}3768 \\
(2107)\end{array}$ & $\begin{array}{l}65.4 \\
(9.2)\end{array}$ & $\begin{array}{l}10.3 \\
(5.9)\end{array}$ & $\begin{array}{c}4.4 \\
(5.2)\end{array}$ & $\begin{array}{l}36.8 \\
(22.9)\end{array}$ \\
\hline
\end{tabular}

Table 2. Dominant amphipod families at stations in the northeastern Chukchi Sea within the area where gray whales occur

\begin{tabular}{|c|c|c|c|c|c|c|c|}
\hline Taxa & $\mathrm{CH} 5$ & $\mathrm{CH} 6$ & $\begin{array}{c}\text { Stations } \\
\mathrm{CH} 7\end{array}$ & $\mathrm{CH} 10$ & $\mathrm{CH} 17$ & Mean (SD) & $\%$ \\
\hline \multicolumn{8}{|c|}{ Dominant amphipod families (ind. $\mathrm{m}^{-2}$ ) } \\
\hline Ampeliscidae & 1644 & 372 & 16 & 1176 & 2530 & $1147(1005)$ & 30.4 \\
\hline Isaeidae & 514 & 4564 & 136 & 36 & 98 & $1070(1962)$ & 28.4 \\
\hline Atylidae & 2 & 874 & 3506 & 0 & 0 & $876(1518)$ & 23.2 \\
\hline \multicolumn{8}{|c|}{ Dominant amphipod families ( $\mathrm{g} \mathrm{C}^{-2}$ ) } \\
\hline Atylidae & $<0.01$ & 1.69 & 12.84 & 0 & 0 & $2.91(5.60)$ & 65.6 \\
\hline Ampeliscidae & 0.63 & 0.48 & 0.01 & 2.99 & 1.74 & $1.17(1.12)$ & 27.3 \\
\hline Isaeidae & 0.06 & 0.50 & 0.01 & 0.02 & $<0.01$ & $0.22(0.28)$ & 0.5 \\
\hline
\end{tabular}

is closely associated with stations of Group IV in this analysis. Stations in offshore Group I are clearly separated from inshore Groups III and IV on plots of first and second, and first and third coordinate axes (Fig. 9b).
Stations in offshore Group II are best separated from inshore Group III on the plot of first and second coordinate axes. Distribution of station groups, based on both multivariate analyses, is shown in Fig. 10.

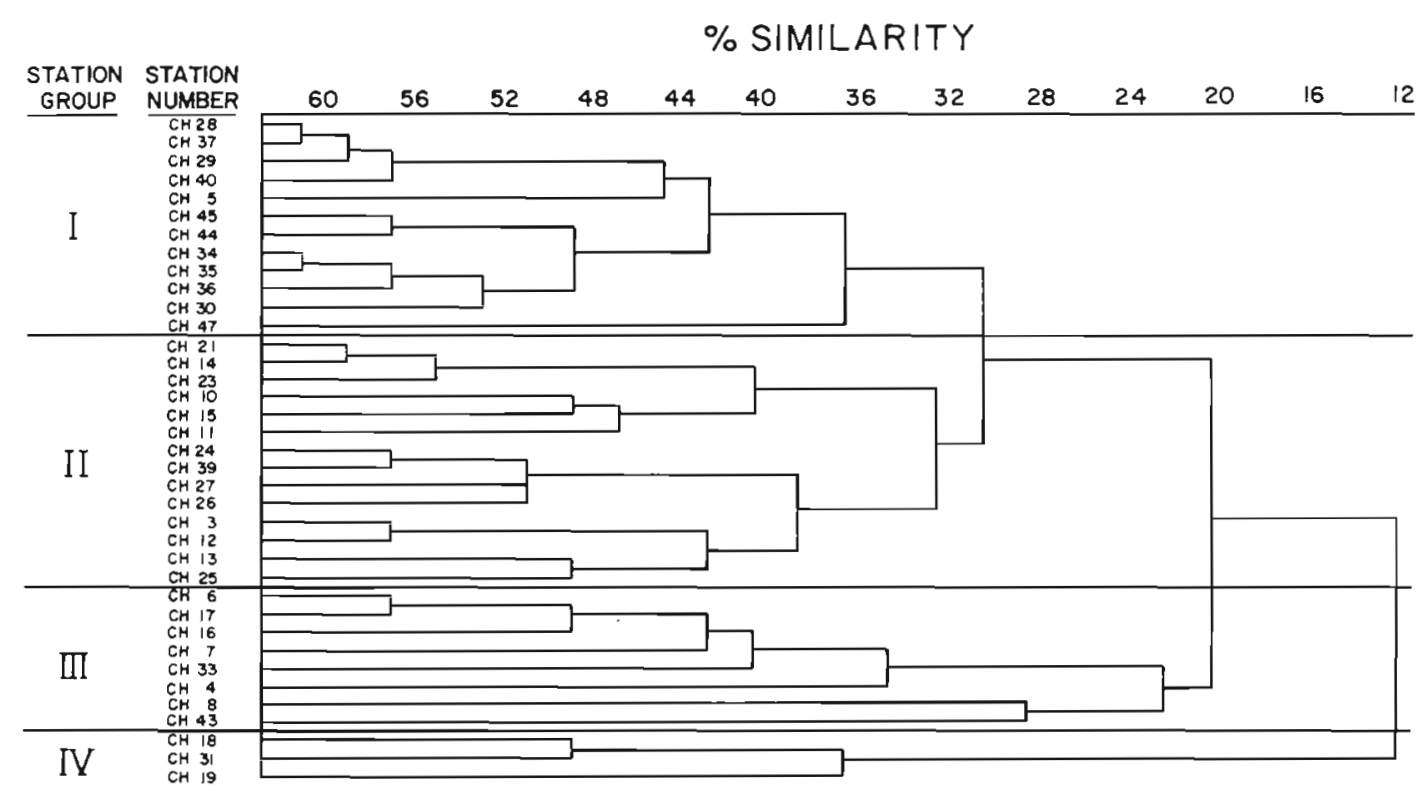

Fig. 8. Dendrogram showing station groups formed by cluster analysis of abundance data based on station-to-station faunal similarities 


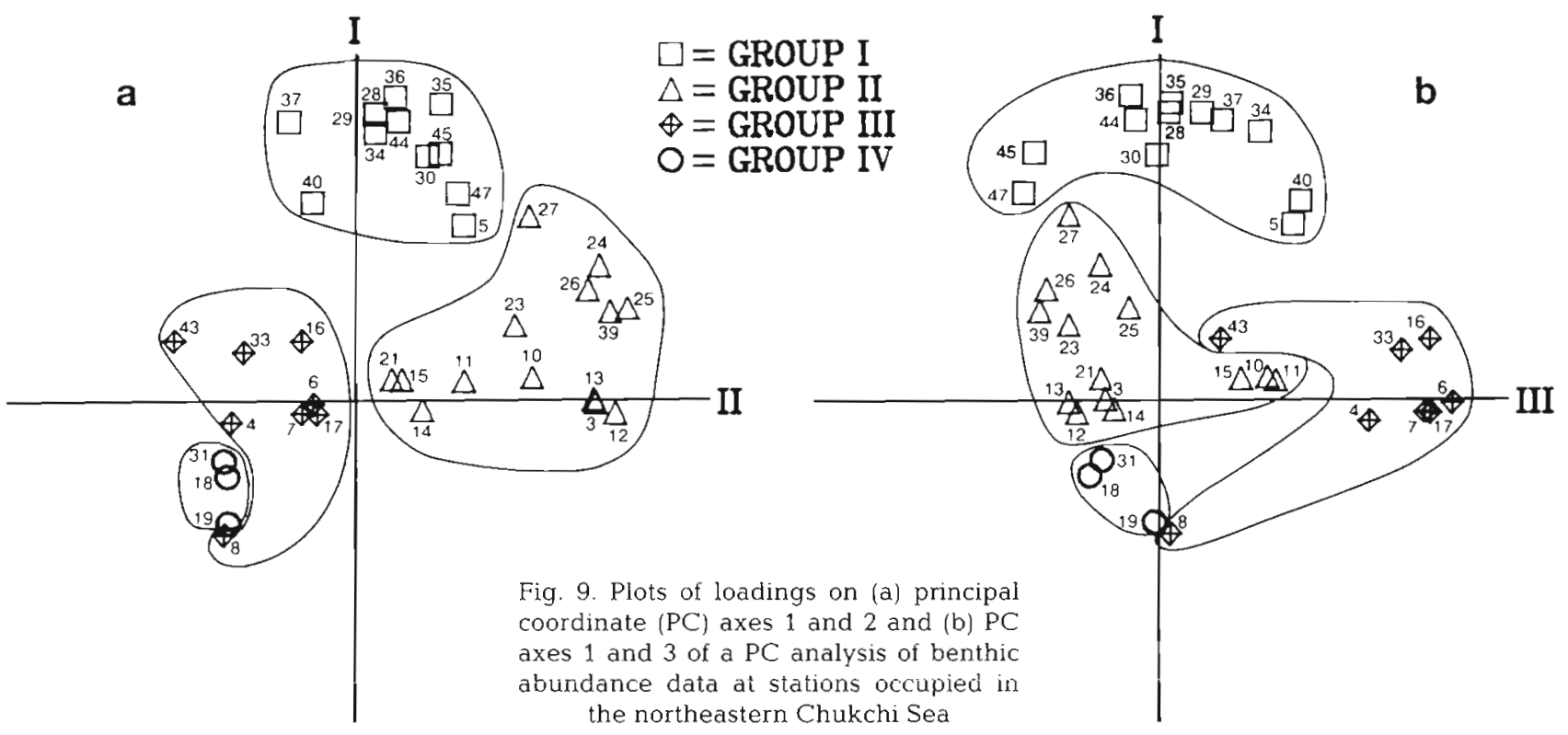

Group I, the most southerly of the offshore groups comprised a muddy-gravel assemblage dominated by juvenile barnacles and the tube-dwelling ampeliscid amphipod Byblis spp. (Table 3). This group had a mean abundance value of 1602 ind. $\mathrm{m}^{-2}$ and a biomass of $6.3 \mathrm{~g} \mathrm{C} \mathrm{m}^{-2}$ (Table 4). Group II, offshore and north of Group I, consisted of a muddy assemblage dominated by the tube-dwelling polychaete Maldane glebifex

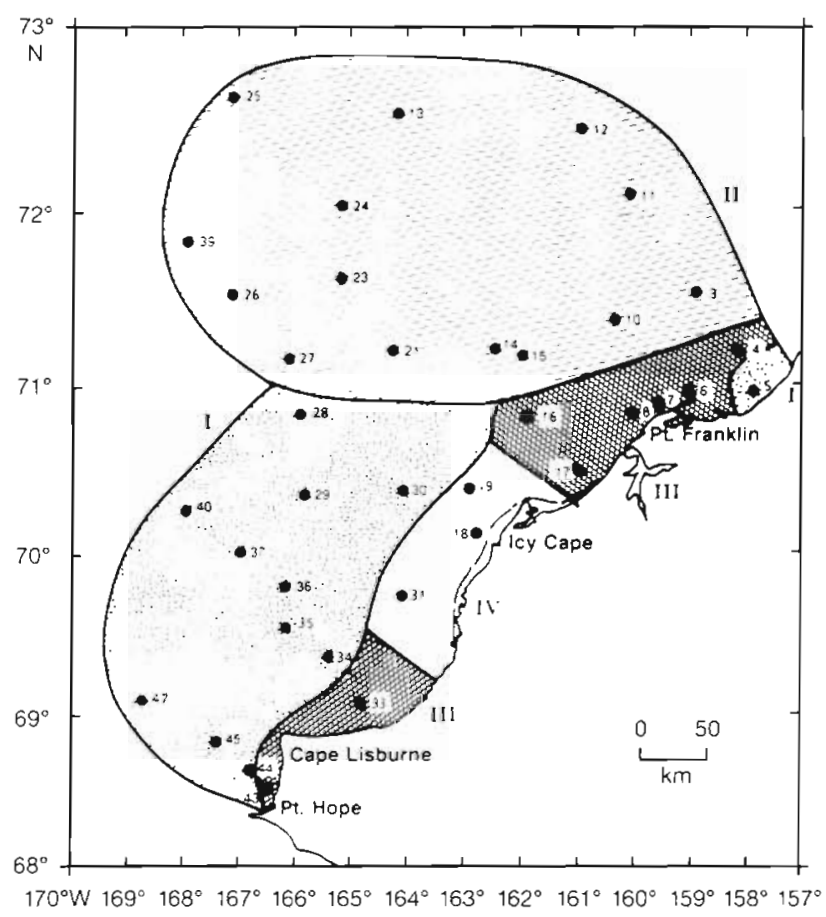

Fig. 10. Distribution of macrofaunal groups based on cluster and principal coordinate analyses of abundance data and the protobranch bivalve Nucula tenuis $(=N$. bellotti). An abundance of 1315 ind $\mathrm{m}^{-2}$ and a biomass of $9.2 \mathrm{~g} \mathrm{C} \mathrm{m}^{-2}$ were recorded here. Group III consisted of stations separated into northern and southern components, and comprised a sand-gravel assemblage dominated by juvenile and adult barnacles and amphipods (primarily Protomedeia spp. and Ampelisca spp.) that accounted for $80 \%$ of the total abundance. This group had the highest abundance ( 8444 ind. $\mathrm{m}^{-2}$ ) and biomass $\left(10.0 \mathrm{~g} \mathrm{C} \mathrm{m}^{-2}\right)$ in the study. Group IV, adjacent to the coast and located between the northern and southern portions of Group III, consisted of a sandy assemblage dominated by the sand dollar Echinarachnius parma. Lowest abundance (929 ind. $\mathrm{m}^{-2}$ ) and biomass $\left(4.9 \mathrm{~g} \mathrm{C} \mathrm{m}^{-2}\right.$ ) occurred here. Shannon indices $\left(H^{\prime}\right)$ were highest and Simpson indices $(D)$ lowest at the 2 offshore station groups (Table 4). $H^{\prime}$ was lowest and $D$ highest at the 2 inshore groups where, as noted above, specific taxa dominated.

The 4 cluster groups were explained by stepwise MDA by a number of sediment parameters. The first analysis, based on dry weight sediment values, excluded percent mud which had a high covariance with percent sand (Table 5, Fig. 11). Discriminant functions (DFs) 1 and 2 contribute $97.8 \%$ of the total separation among station groups. A total of $62.2 \%$ of the stations were correctly grouped by the jackknife classification into station groups by the 3 variables that form the discriminant functions. The lowest negative value along DF 1 is due to the percentage of sand. The next lowest negative value along DF 1 is sediment OC/N. The high positive value along DF 2 is the result of the percentage of gravel in sediment. A negative value along DF 2 is due to the $\mathrm{OC} / \mathrm{N}$ value of the sediment. The centroid 
Table 3. Dominant taxa, in terms of abundance, and percent occurrence of taxa within station groups

\begin{tabular}{|c|c|c|c|c|c|}
\hline Group & $\begin{array}{l}\text { Stations } \\
\text { in group }\end{array}$ & $\%$ Similarity & Dominant taxa & $\begin{array}{l}\text { Mean abundance } \\
\quad \text { (ind } \mathrm{m}^{-2} \text { ) }\end{array}$ & $\begin{array}{l}\% \text { Occurrence } \\
\text { in group }\end{array}$ \\
\hline I & $\begin{array}{l}28,37,29 \\
40,5,45 \\
44,34,35 \\
36,30,47\end{array}$ & 36 & $\begin{array}{l}\text { Byblis gaimardi } \\
\text { Balanus crenatus (juvenile) } \\
\text { Leitoscoloplos pugettensis } \\
\text { Nucula tenuis } \\
\text { Echiurus echiurus alaskensis } \\
\text { Cirratulidae } \\
\text { Barantolla americana } \\
\text { Maldane glebifex } \\
\text { Protomedeia spp. } \\
\text { Thyasira gouldi }\end{array}$ & $\begin{array}{r}140 \\
135 \\
85 \\
85 \\
81 \\
73 \\
66 \\
63 \\
56 \\
36\end{array}$ & $\begin{array}{r}92 \\
92 \\
100 \\
100 \\
83 \\
100 \\
100 \\
100 \\
83 \\
83\end{array}$ \\
\hline II & $\begin{array}{l}21,14,23 \\
10,15,11 \\
24,39,27 \\
26,3,12 \\
13,25\end{array}$ & 32 & $\begin{array}{l}\text { Nucula tenuis } \\
\text { Maldane glebifex } \\
\text { Lumbrineris sp. } \\
\text { Macoma calcarea } \\
\text { Cirratulidae } \\
\text { Barantolla americana } \\
\text { Leitoscoloplos pugettensis } \\
\text { Haploops laevis }\end{array}$ & $\begin{array}{r}161 \\
148 \\
78 \\
64 \\
33 \\
24 \\
23 \\
21\end{array}$ & $\begin{array}{r}100 \\
86 \\
100 \\
100 \\
93 \\
100 \\
86 \\
71\end{array}$ \\
\hline III & $\begin{array}{l}6,17,16 \\
7,33,4 \\
8,43\end{array}$ & 22 & $\begin{array}{l}\text { Balanus crenatus (juvenile) } \\
\text { Protomedeia spp. } \\
\text { Balanus crenatus } \\
\text { Ampelisca macrocephala } \\
\text { Ischyrocerus sp. } \\
\text { Leitoscoloplos pugettensis } \\
\text { Cirratulidae } \\
\text { Ampelisca eschrichti } \\
\text { Urochordata } \\
\text { Pholoe minuta }\end{array}$ & $\begin{array}{r}4159 \\
437 \\
346 \\
298 \\
106 \\
77 \\
62 \\
56 \\
56 \\
41\end{array}$ & $\begin{array}{l}88 \\
88 \\
60 \\
76 \\
76 \\
88 \\
88 \\
63 \\
63 \\
88\end{array}$ \\
\hline IV & $18,31,19$ & 36 & $\begin{array}{l}\text { Echinarachnius parma } \\
\text { Scoloplos armiger } \\
\text { Spiophanes bombyx } \\
\text { Glycinde wireni } \\
\text { Liocyma viridis } \\
\text { Amphiophiura sp. }\end{array}$ & $\begin{array}{r}276 \\
37 \\
21 \\
11 \\
11 \\
11\end{array}$ & $\begin{array}{r}100 \\
100 \\
67 \\
100 \\
67 \\
67\end{array}$ \\
\hline
\end{tabular}

of Group IV is distinct from that of Groups I, II, and III along the axis of DF 1. The centroids of Groups I and II are separated from Group III on DF axes 1 and 2. Group II is distinct from Group I along the DF 1 and 2 axes. The separation of Group IV from Groups I, II, and
III is mainly the result of the higher percentage of sand in sediment of Group IV and also the higher OC/N value within Group IV. The difference in percent gravel results in separation of Groups I and II, as well as separation of both groups from Group III.

Table 4. Abundance $[\bar{X}(S D)]$, biomass $[\bar{X}(S D)]$, number of taxa, Simpson dominance $(D)$ and Shannon diversity $\left(H^{\prime}\right)$ indices, and species richness of station groups

\begin{tabular}{|ccccccc|}
\hline Group & $\begin{array}{c}\text { Abundance } \\
\left.\text { (ind. } \mathrm{m}^{-2}\right)\end{array}$ & $\begin{array}{c}\text { Biomass } \\
\left(\mathrm{g} \mathrm{C} \mathrm{m}^{-2}\right)\end{array}$ & $\begin{array}{c}\text { No. of } \\
\text { taxa }\end{array}$ & D & $\begin{array}{c}\text { Species } \\
\text { richness }\end{array}$ \\
\hline I & $1602(953)$ & $6.3(2.9)$ & 172 & 0.04 & 3.65 & 23.5 \\
II & $1315(1094)$ & $9.2(3.9)$ & 204 & 0.05 & 3.84 & 28.6 \\
III & $8444(9655)$ & $10.0(6.5)$ & 248 & 0.29 & 2.47 & 72.5 \\
IV & $929(612)$ & $4.9(1.5)$ & 64 & 0.18 & 2.39 \\
\hline
\end{tabular}


Table 5. Summary of the stepwise multiple discriminant analyses of the environmental conditions among the 4 station groups formed by cluster analyses of abundance data. Sediment data used in the analyses are based on dry weight values. Percent mud, which has a high covariance with sand, has been excluded

\begin{tabular}{|lccc|}
\hline Discriminant function: & 1 & 2 & 3 \\
\hline Percent separation & 71.61 & 26.19 & 2.20 \\
Cumulative separation & 71.61 & 97.80 & 100.00 \\
& \multicolumn{3}{c}{} \\
Variable & Standardized function coefficients \\
\hline Percent gravel & -0.30 & 0.95 & - \\
Percent sand & -0.91 & 0.36 & - \\
Sediment OC/N & -0.53 & -0.72 & - \\
\hline
\end{tabular}

Another MDA was based on wet weight of sediment; again, mud was excluded. DF 1 contributed $83.7 \%$ of the total separation among groups of stations (Table 6 , Fig. 12). A total of $75.7 \%$ of the stations were correctly grouped by the jackknife classification into station groups by the 2 variables that form the discriminant functions. The variables are percentage of water within sediment and sediment $O C / N$ value. A high positive value along DF 1 is due to the high percentage of water in sediment. The negative value along DF 1 is due to the high $\mathrm{OC} / \mathrm{N}$ value of sediments. The centroids of Groups I and II are distinct from those of Groups III and IV along the axis DF 1. Separation of Groups I and II from III and IV is due to the higher percentage of water and lower OC/N values in sediments
Table 6. Summary of the stepwise multiple discriminant analyses of the environmental conditions among the 4 station groups. All sediment data used in the analyses are based on wet weight values

\begin{tabular}{|lcr|}
\hline Discriminant function: & 1 & 2 \\
\hline Percent separation & 83.65 & 16.35 \\
Cumulative separation & 83.65 & 100.00 \\
Variables & Standardized function coefficients \\
\hline Percent water in sediment & 0.96 & -0.29 \\
Sediment OC/N & -0.17 & -0.94 \\
\hline
\end{tabular}

of Groups I and II. Separation of inshore Group III from IV, and Group I from II is apparent along the axis of DF 2 , and is due primarily to higher sediment $\mathrm{OC} / \mathrm{N}$ values at Groups IV and II, respectively. The relationship of sediment parameters to cluster groups is also evident in a ternary diagram relating stations to \% water, gravel + sand, and mud (silt and clay) (Fig. 13).

Feeding types. Feeding types within station groups varied according to location and substrate type (Table 7, Figs. 11 \& 13). Within coastal Groups III (sandy-gravel substrate) and IV (sandy substrate), suspension-feeding taxa (SF) were significantly more abundant ( 49 and $66 \%$ of total abundance, respectively: $p \leq 0.05$ ) than other feeding types. At muddy, offshore Groups I and II the fauna was dominated by surface (SDF) and subsurface deposit feeders (SSDF) compared to other feeding types in the groups ( $\mathrm{p} \leq$ $0.05)$.

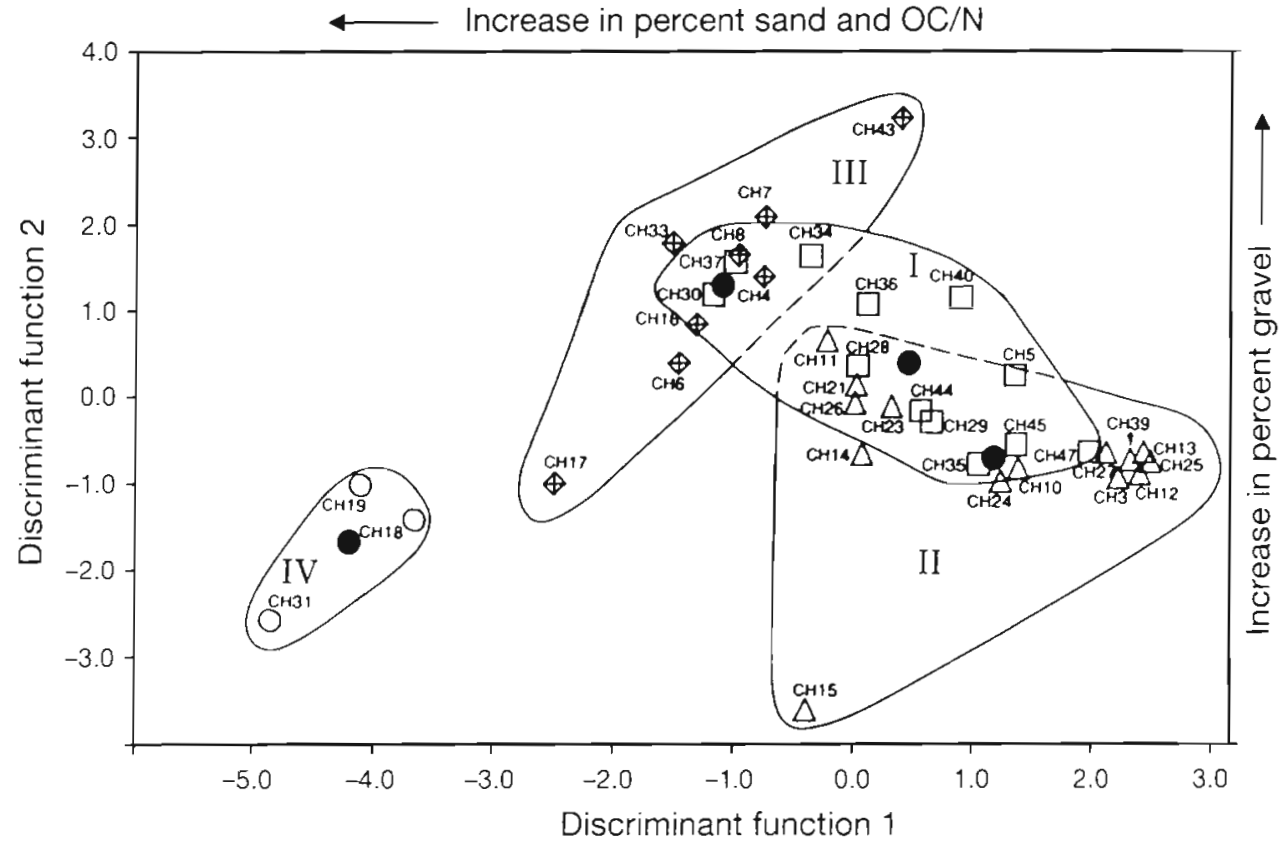

Fig. 11. Station plot of the results of a stepwise multiple discriminant analysis utilizing environmental variables recorded in the study. The analysis is based on dry sediment weight. (-) Centroids of the 4 respective station groups 
Fig. 12. Station plot of the results of a stepwise multiple discriminant analysis analysis utilizing environmental variables recorded in the study. The analysis is based on wet sediment weight. (o) Centroids of the 4 respective station groups

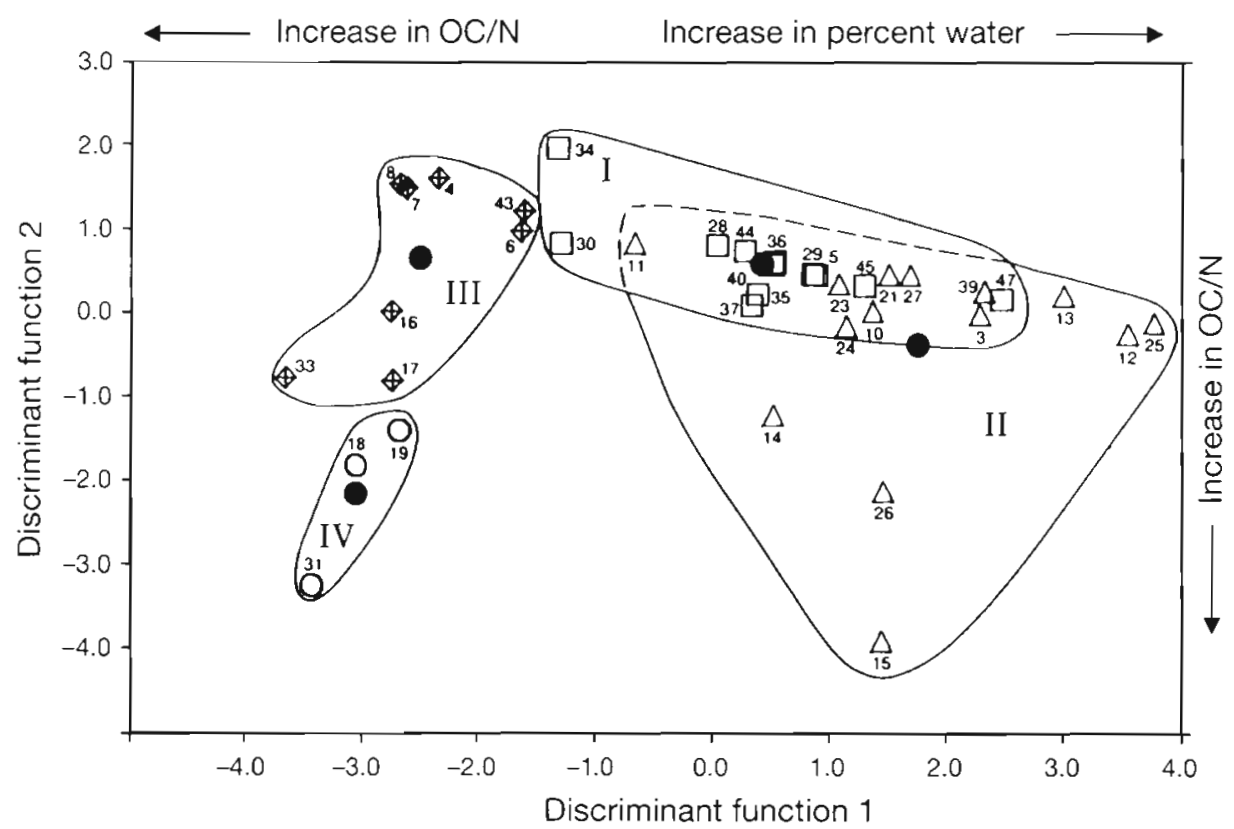

\section{DISCUSSION}

\section{Factors affecting benthic abundance and composition of benthic groups}

Benthic faunal assemblages, based on taxonomic abundance, in many areas have been determined on the basis of sediment geotechnical properties, as influenced by granulometry, water content, and amount of organic carbon (e.g. Boswell 1961, Day et al. 1971, Franz 1976, McCave 1976, Webb 1976, Flint 1981, Mann 1982, Weston 1988). The 4 benthic station groups described in this paper are best explained, based on discriminant analysis, by the relative amount of gravel, sand, and mud, OC/N values and percentage of water in sediment. Trophic mode segregation by deposit and suspension feeders is well documented (Rhoads 1974), and sediment preferences of the 2 feeding groups are reported from many subtidal benthic studies (e.g. Sanders 1960, Young \& Rhoads 1971, Long \& Lewis 1987). Sediment preferences of the 2 major feeding groups in our study area were similar to those reported elsewhere.
Fig. 13. Ternary diagram relating stations to station groups based on percentage of water, gravel, sand and mud. Stations within benthic biological station groups are encompassed by solid lines
The sediment of our offshore Groups I and II had a higher content of mud and water than inshore Groups III and IV. Dominance in northern offshore Group II of 2 subsurface deposit-feeding taxa, the tube-dwelling polychaete Maldane glebifex and the protobranch clam Nucula tenuis, and the surface deposit-feeding clam Macoma calcarea (Table 3) is probably related to

\section{.

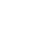

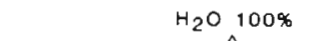


Table 7 . Percentage $[\bar{x}(\mathrm{SD})]$ by abundance (ind. $\mathrm{m}^{-2}$ ) of feeding types within station groups. SDF: surface deposit feeder; SF: suspension feeder; SSDF: subsurtace deposit feeder; PRED: predator; SCAV: scavenger; HERB: herbivore

\begin{tabular}{|c|c|c|c|c|c|c|}
\hline Group & $\begin{array}{c}\text { SDF } \\
\%\end{array}$ & $\begin{array}{l}\text { SF } \\
\%\end{array}$ & $\begin{array}{c}\text { SSDF } \\
\%\end{array}$ & $\begin{array}{c}\text { PRED } \\
\%\end{array}$ & $\begin{array}{c}\text { SCAV } \\
\%\end{array}$ & $\begin{array}{c}\text { HERB } \\
\%\end{array}$ \\
\hline$I^{d}$ & $32.16(15.89)$ & $14.08(11.82)$ & $34.03(17.23)$ & $7.13(2.33)$ & $7.74(3.35)$ & $0.65(0.74)$ \\
\hline II ${ }^{\mathrm{a}}$ & $31.30(14.12)$ & $10.65(5.99)$ & $32.63(16.80)$ & $11.78(3.52)$ & $6.56(2.73)$ & $3.46(2.20)$ \\
\hline $\operatorname{III}^{\mathrm{b}}$ & $25.16(24.90)$ & $48.59(34.21)$ & $4.31(3.10)$ & $6.35(4.07)$ & $10.17(9.36)$ & $4.31(8.58)$ \\
\hline$I^{b}$ & $5.99(4.76)$ & $66.49(16.88)$ & $8.84(4.53)$ & $8.14(3.90)$ & $6.75(3.96)$ & $0.35(0.10)$ \\
\hline
\end{tabular}

the higher substrate fluidity resulting from the high mud and water content of sediment there (Fig. 13). Presumably this fluidized mud offers an optimum substrate for tube building by $M$. glebifex, and provides easy access by $M$. glebifex, $N$. tenuis and $M$. calcarea to POC associated with such sediments. Close association of POC with muddy sediments is demonstrated by numerous investigators (see Weston 1988 for review), including those working on the Alaskan arctic shelf (Naidu \& Hood 1972, Naidu 1985). However, within the generally muddy substrate of Groups I and II, there are subtle sediment variations, such as the higher admixture of coarse grains and lower water content within the substrate of Group I (Figs. $11 \& 13$ ). The substrate variations are reflected by differences in dominant taxa within the 2 groups (Table 3). Thus, southern offshore Group I, with a higher content of gravel, is dominated by the surface-deposit feeding ampeliscid amphipod Byblis gaimardi and juvenile barnacles Balanus crenatus while northern Group II by the subsurface deposit feeders $N$. tenuis and $M$. glebifex and the surface-deposit feeder $M$. calcarea. The presence of juvenile, but not adult, barnacles in Group I suggests that they are smothered after settlement by the relatively high sedimentation offshore (Fig. 4; M. Baskaran \& A. S. Naidu unpubl. data).

Separation of inshore Group III from IV is due to a higher content of gravel and lower content of sand within the substrate of Group III (Fig, 11). This group is dominated by juvenile and adult barnacles which is consistent with the presence of gravels concentrated under intense coastal currents. These coastal areas are also characterized by occasional rocky outcrops (Phillips et al. 1985a, b), which reflect a high energy hydrodynamic environment conducive to barnacle survival. At some stations in the northern portion of Group II large numbers of ampeliscid amphipods were present where the substrate is favorable for the tubebuilding activities of these crustaceans (Tables $1 \& 2$ ). Success of amphipods here appears to be controlled primarily, as discussed later, by high deposition of POC to the seafloor surface. The presence at inshore Group IV of a relatively large resident population of the sand dollar Echinarachnius parma is made possible by the presence of a gravel-poor sandy substrate (Fig. 11). Success of the suspension-feeding sand dollar in this area is probably a result of the prevalence of strong currents associated with Alaska Coastal Water (ACW; Phillips 1987) which entrains fine sediments and associated POC as a food resource (Burbank 1974). Low Shannon diversity and high Simpson dominance values within Group IV (Table 4) appear related to stresses induced by strong currents and sedimentreworking activities of sand dollars there (Brenchley 1981, Smith 1981, Highsmith 1982). It would seem that ice gouging of the bottom described for this region (Grantz et al. 1982) is not a factor in species reduction here, as this stress would be expected to equally affect the large sand dollars at the sediment surface. The higher amount of sand, relative to gravel, in the substrate of Group IV compared to the adjacent Group III is most likely related to the sand transported and deposited by littoral currents and river outflow. This is reflected by the local presence of sandy barrier islands and turbid fluvial discharge immediately south of Icy Cape (Truett 1984).

Our studies indicate that, in the context of sediment sorting, there is an important difference between distributional patterns of benthos in our study area and those of the adjacent southeastern Chukchi and northeastern Bering Sea shelves (Grebmeier et al. 1989 Feder et al. 1990). Grebmeier et al. (1989) related benthic diversity values in the northeastern Bering Sea to sediment heterogeneity (sediment sorting). They reported highest diversities at nearshore stations where sediments were poorly sorted and lowest diversity offshore where sediments were relatively well sorted. In the southeastern Chukchi Sea, Grebmeier et al. (1989) and Feder et al. (1990) indicate that diversity increases offshore where more heterogeneous sedi- 
ments occur. In contrast, our studies in the northeastern Chukchi Sea demonstrate that sediments, close to shore and further offshore, are typically poorly to extremely poorly sorted. Consequently, differences in benthic faunal diversity between inshore and offshore regions in the northeast Chukchi Sea are not related to differences in sediment sorting. Instead, we believe that offshore/inshore dissimilarities in diversity in our study area are related to regional differences, as discussed below, in environmental stress. Inshore waters of the Chukchi Sea are subject to greater bottom disturbance by the action of strong currents, local eddies and gyres, ice gouging, migrating sand waves associated with intense wave/current action, and feeding activities of sand dollars, gray whales and walrus (Barnes 1972, Toimil 1978, Fay 1982, Phillips \& Reiss 1985a, b, Klaus et al. 1990). These factors result in a more fluctuating, stressful environment inshore than offshore. Thus, it is not surprising that benthic populations inshore in the northeastern Chukchi Sea have lower Shannon diversity and higher Simpson dominance values than offshore.

A knowledge of the origin and dispersal of water masses is often helpful to explain taxonomic distribution and abundance of benthic invertebrates, primarily because water masses play an important role in characterization of the physical environment, distribution of food resources and dispersal of planktonic larvae of benthic species (Thorson 1957, Creutzberg et al. 1984, Stewart et al. 1985). In this study, no statistical relationship between salinity and temperature of water masses and station groups was determined. Nevertheless, a broad association of station groups with major water masses was apparent (Fig. 10; see 'Study area'). Thus, taxa at offshore Groups I and II were generally those associated with Bering Shelf Water (BSW) whereas taxa of Group IV and the southern segment of inshore Group III generally coincided with ACW. Such an association of benthic taxa with $\mathrm{ACW}$ is consistent with observations of Feder et al. (1985) and Grebmeier et al. (1989) in the contiguous northeastern Bering Sea. This broad association of specific taxa, within the station groups, with water masses is to be expected based on known differences in the hydrodynamics of the water masses and their effects on the requirements of inshore and offshore species

There can be factors, other than those discussed above, that affect benthic abundance in our study area. For example, numerous studies have shown that ice scouring disrupts and modifies the sea bed over much of the continental shelf of arctic seas, affecting sediments and associated fauna (Barnes \& Reimnitz 1974, Carey et al. 1974, Grantz et al. 1982, Barnes et al. 1984, Phillips et al. 1985a, b, Carey 1991, Woodworth-Lynas et al. 1991). In our study area, we expected a progres- sive increase in benthic abundance across the shelf to deeper water because the inshore area, which is potentially more pervasively affected by ice gouging (Phillips et al. 1985a, b), should have had relatively lower benthic abundance than farther offshore. Instead, abundance values were either similar or higher inshore than offshore (Appendix II), suggesting that ice gouging was not an important factor controlling benthic abundance in the study area. It is probable that the recurring presence in winter of polynyas, openwater areas within ice-covered seas, along the inner shelf areas of the northeastern Chukchi Sea (Stringer \& Groves 1991) minimizes the intensity of ice gouging which results in benthic abundance values similar to or greater than those offshore. In contrast, in the adjacent Alaskan Beaufort Sea, where polynyas are virtually absent, ice gouging results in lowered benthic abundance inshore (Carey et al. 1974, Feder \& Schamel 1976, Carey 1991).

As mentioned previously, ampeliscid amphipods occurred in high abundance inshore, predominantly on sandy-gravel substrate, in the vicinity of Point Franklin (Table 1). This finding is in contrast to that of Grebmeier et al. (1989) for the northeastern Bering Sea where ampeliscids were uncommon inshore on sandygravel bottom. These regional differences, as discussed below, can be explained by cross-shelf differences in the supply of POC to the crustaceans in the 2 areas rather than sediment composition (Coyle \& Highsmith 1994).

\section{Factors affecting benthic biomass}

As mentioned earlier, carbon biomass values in our study area were higher north of a hydrographic front (Fig, 7) in waters with bottom-water salinities and temperatures typical of BSW (Walsh et al. 1989a, b). Likewise, we determined that carbon biomass values for stations occupied by Stoker (1978) in the northeastern Chukchi Sea were also higher ( $p \leq 0.01$ ) north of the front. As discussed below, we attribute the regional biomass differences to a relatively larger supply and deposition of POC in the region north of the frontal system. A portion of BSW, entrained with high levels of POC, having a primary source in the northern Bering and southeastern Chukchi Seas (Whitledge et al. 1986, 1992, Walsh et al. 1989a, b, Korsak 1992, Robie et al. 1992, Zeeman 1992), extends to the region adjacent to Point Franklin within the northeastern Chukchi Sea (Spaulding et al. 1987, Johnson 1989, Walsh et al. $1989 \mathrm{a}, \mathrm{b})$. The BSW that flows northward along the eastern flank of Herald Shoal (Fig. 2) demonstrates high fluorescence values (a proxy for POC concentration) in fall (Weingartner 1993). This, as suggested by 
Weingartner, indicates that the region east of Herald Shoal represents an important route for flux of POC to the area adjacent to Point Franklin. We believe that a portion of the POC thus advected northeastward is deposited into the northern portion of our study area. This conjecture is supported by the higher $(p=0.03)$ sediment organic carbon values $(\bar{x}=8.5 \pm 3.9 \mathrm{mg} \mathrm{C}$ $\mathrm{g}^{-1}$ ) for stations north of the front compared to those to the south to Cape Lisburne $\left(\bar{x}=5.7 \pm 1.3 \mathrm{mg} \mathrm{C} \mathrm{g}^{-1}\right)$ (Fig. 5). Based on the foregoing we suggest that the high benthic biomass north of the bottom front results, in part, from an allochthonous supply of POC that enhances the locally produced food source to the benthos. This conclusion, which is similar to that arrived at for the adjacent northeastern Bering and Chukchi Seas by Grebmeier et al. (1988) and Feder et al. (1990), suggests that higher benthic biomass is associated with the nutrient-rich waters seaward of a hydrographic front extending from the northeastern Bering Sea to our study area (Weingartner pers. comm.).

There are other factors that probably contribute POC to support the high biomass north of the frontal zone in the study area. For example, there are sufficient nutrients in the water column at the pycnocline north of the frontal system to locally enhance phytoplankton production (Fig. 6). The corresponding supersaturation of oxygen $\left(>7.3 \mathrm{ml} \mathrm{l}^{-1}\right)$ indicates that production processes exceed water-column respiration. The accumulation of oxygen during the ice-free period would be equivalent to a net primary production of about $50 \mathrm{~g} \mathrm{C} \mathrm{m}^{-2}$ (Whitledge \& Salo 1991) which may serve as a source of POC to the benthos. The presence of relatively high nutrients north of the front in the nearshore zone from Icy Cape to Point Barrow is presumably a result of upwelling there (Johnson 1989, Aagaard \& Roach 1990, Feder et al. 1994). Additionally, polynyas are reported to enhance water-column production in arctic regions (Dunbar 1981, Arctic Ocean Science Board 1988, 1989, Massom 1988, Smith et al. 1990). As mentioned previously, polynyas occur within the inshore region north of the front (Stringer \& Grove 1991); therefore, high benthic biomass north of the front in our study area may reflect, in part, increased input of phytodetritus produced within polynyas to supplement advected sources of carbon. This suggestion is consistent with the enhanced meio- and macrofaunal populations observed under the Northeast Water Polynya in Greenland (Piepenburg 1988, Deming et al. 1993). Other sources of carbon to the benthos in the vicinity of Point Franklin, where high benthic biomass occurred, are local beds of macroalgae (primarily Laminaria saccharina and L. solidungula) (Truett 1984, Phillips \& Reiss 1985a, b, also see discussions in Duggins et al. 1988 and Dunton et al. 1989).
It is apparent that $\mathrm{POC}$ enrichment of the bottom in the northern margin of the study area persists on a long-term basis. This is supported by several biological observations. Ampeliscid arnphipods in the northeastern Chukchi Sea are common to abundant adjacent to and north of the bottom front under BSW and Resident Chukchi Water (RCW) but typically rare landward of the front under $\mathrm{ACW}$. We contend that this distribution pattern of amphipods, which is similar to that observed in the adjacent northeastern Bering Sea relative to the front (Grebmeier et al. 1989, Highsmith \& Coyle 1992), is to be explained by regional differences in the amount of POC supplied to the bottom. Based on calculations by Coyle \& Highsmith (1994) for the adjacent northeastern Bering Sea, absence of ampeliscids under ACW results from a carbon flux to the bottom that is too low to sustain them. Thus, presence of large numbers of tube-dwelling ampeliscids, inclusive of the large Ampelisca macrocephala, along the coast north of the bottom front in the northeastern Chukchi Sea supports our contention that a high carbon flux to the bottom must occur there. The benthos in the latter region is numerically dominated by the same amphipods that characterize major graywhale feeding grounds in the northeastern Bering Sea (Klaus et al. 1990). The annual summer return north of Point Franklin of populations of gray whales, which feed primarily on these amphipods (Moore \& Clarke 1986, Clarke et al. 1987, Highsmith \& Coyle 1992), and walrus, which also feed on amphipods there (Fay 1982, Feder et al. 1989), indicates that carbon is available on a long-term basis. Additionally, sediment reworking by bottom-feeding gray whales (Moore \& Clarke 1986) and walrus (Fay 1982) transfers POC derived from subsurface sediments onto the sea-floor surface (also described for the adjacent northeastern Bering Sea by Oliver \& Slattery 1985). This POC supplements primary settling POC and enhances success of opportunistic species such as ampeliscid amphipods (Feder et al. 1989, also see Boesch \& Rosenberg 1981, Jones \& Candy 1981, Thistle 1981, Poiner \& Kennedy 1984 for reviews of this process). An abundant motile scavenger/predator amphipod group in the study area, the Atylidae (Feder et al. 1989, this paper), moves into marine mammal excavations in large numbers (Klaus et al. 1990), and its presence is indicative of intensive marine-mammal foraging activities there.

\section{CONCLUSIONS}

Four benthic assemblages identified in the northeastern Chukchi Sea are best explained by gravelsand-mud, OC/N and water content variations of bottom sediments. In the context of sediment sorting, 
there is an important difference between distributional patterns of benthos in our study area and those reported by earlier workers for the adjacent southeastern Chukchi and northeastern Bering Sea shelves. In the latter regions, faunal diversity and sediment sorting were strongly correlated. However, within the northeastern Chukchi Sea such a relationship was not observed because all sediments had similar sorting values. It is suggested that low faunal diversity inshore within our study area is related to greater environmental stresses there. The presence north of a bottom front of a notably high benthic biomass, attended by abundant populations of amphipods (primarily ampeliscids) and other macrobenthic organisms, is related to a large local flux of POC to the bottom. We believe that POC-rich waters derived from the northern Bering and southern Chukchi Seas extend to the northeastern Chukchi Sea to augment locally produced carbon and thus provide a persistent annual source of carbon to the benthos there. Annual return in summer, to the region north of the bottom front, of feeding populations of gray whales and walrus indicates the presence of a persistent and reliable source of benthic food. Disturbance of the inshore bottom in the above region by the combined action of currents, waves, ice gouging and feeding activities of marine mammals results in a stressed environment where opportunistic benthic species, such as ampeliscid amphipods, have become established. Success of these species and the marine mammals that feed on them is further enhanced by advection of POC as suggested above. This study demonstrates that there can be high standing stocks of benthos in arctic regions with relatively low annual primary production if local carbon is augmented by POC advected from highly productive areas.

Appendix 1. The percentages of gravel (Gr), sand (Sd), silt (St), clay (Cl) and mud in the substrate and the percentage of water in bottom sediments at each station. Mz: mean sediment size. Concentrations of suspended particles (BWSP) in waters $5 \mathrm{~m}$ above bottom and content of organic carbon in the sediment particles (OCBWSP). Concentrations of organic carbon (OC), nitrogen ( $N$ ) and the $O C / N$ ratio in bottom sediments

\begin{tabular}{|c|c|c|c|c|c|c|c|c|c|c|c|c|c|}
\hline Stn & $\begin{array}{c}\mathrm{Gr} \\
(\%)\end{array}$ & $\begin{array}{c}\mathrm{Sd} \\
(\%)\end{array}$ & $\begin{array}{c}S t \\
(\%)\end{array}$ & $\begin{array}{c}\mathrm{Cl} \\
(\%)\end{array}$ & $\begin{array}{c}\text { Mud } \\
(\%)\end{array}$ & $\begin{array}{l}\mathrm{Mz} \\
(\phi)\end{array}$ & $\begin{array}{c}\text { Sorting } \\
(\delta)\end{array}$ & $\begin{array}{c}\text { Water } \\
(\%)\end{array}$ & $\begin{array}{c}O C \\
\left(\mathrm{mg} \mathrm{g}^{-1}\right)\end{array}$ & $\begin{array}{c}\mathrm{N} \\
\left(\mathrm{mg} \mathrm{g}^{-1}\right)\end{array}$ & $O C / N$ & $\begin{array}{c}\text { BWSP } \\
\left(\mathrm{mg} \mathrm{l}^{-1}\right)\end{array}$ & $\begin{array}{c}\text { OCBWSP } \\
\left(\mu \mathrm{gl}^{-1}\right)\end{array}$ \\
\hline $\mathrm{CH} 3$ & 0.0 & 3.2 & 58.8 & 38.1 & 96.8 & 6.2 & 1.7 & 45.1 & 5.32 & 0.66 & 8.10 & 1.0 & - \\
\hline $\mathrm{CH} 4$ & 18.1 & 70.2 & 5.6 & 6.0 & 11.7 & 2.7 & 4.2 & 16.2 & 11.86 & 1.55 & 7.70 & 1.1 & - \\
\hline $\mathrm{CH} 5$ & 15.4 & 19.2 & 40.0 & 25.4 & 65.4 & 6.4 & 3.3 & 35.6 & 5.98 & 0.75 & 8.00 & 3.6 & - \\
\hline $\mathrm{CH} 6$ & 1.0 & 84.2 & 10.2 & 4.6 & 14.8 & 2.9 & 1.4 & 20.7 & 4.31 & 0.51 & 8.50 & 1.8 & 86 \\
\hline $\mathrm{CH} 7$ & 34.2 & 61.4 & 2.6 & 1.8 & 4.4 & -1.3 & 2.9 & 15.2 & 8.24 & 1.02 & 8.08 & 2.0 & 103 \\
\hline CH8 & 23.9 & 70.5 & 2.8 & 2.8 & 5.6 & 0.5 & 2.2 & 14.9 & 10.02 & 1.25 & 8.00 & 1.9 & 98 \\
\hline $\mathrm{CH}$ & 0.0 & 11.5 & 47.7 & 40.7 & 88.5 & 7.5 & 3.1 & 47.8 & 8.60 & 1.07 & 8.00 & 1.5 & 84 \\
\hline $\mathrm{CH} 10$ & 0.0 & 22.3 & 49.0 & 28.6 & 77.7 & 6.4 & 3.0 & 39.4 & 3.76 & 0.44 & 8.60 & 3.4 & 128 \\
\hline $\mathrm{CH} 11$ & 12.6 & 58.5 & 20.0 & 8.8 & 28.9 & 2.0 & 3.0 & 26.0 & 7.25 & 0.88 & 8.20 & 1.6 & 93 \\
\hline $\mathrm{CH} 12$ & 0.0 & 0.2 & 91.0 & 8.9 & 99.8 & 8.1 & 2.3 & 53.2 & 4.43 & 0.57 & 7.80 & 4.4 & 145 \\
\hline $\mathrm{CH} 3$ & 0.0 & 3.4 & 51.3 & 45.3 & 96.6 & 8.5 & 3.0 & 48.9 & 13.76 & 1.92 & 7.20 & 3.2 & 191 \\
\hline $\mathrm{CH} 14$ & 18.6 & 27.3 & 34.0 & 20.1 & 54.2 & 5.5 & 1.8 & 37.3 & 9.62 & 0.82 & 11.70 & 2.6 & 212 \\
\hline $\mathrm{CH} 15$ & 0.0 & 16.3 & 44.5 & 39.3 & 83.7 & 7.4 & 3.3 & 49.3 & 13.54 & 0.81 & 16.70 & 0.6 & 106 \\
\hline CH16 & 32.1 & 57.8 & 6.2 & 3.9 & 10.1 & 1.0 & 2.9 & 17.2 & 5.71 & 0.51 & 11.20 & 0.6 & 88 \\
\hline $\mathrm{CH} 17$ & 2.7 & 82.9 & 9.6 & 4.8 & 14.4 & 1.5 & 2.7 & 18.8 & 6.21 & 0.48 & 12.90 & 1.1 & 95 \\
\hline $\mathrm{CH} 18$ & 4.8 & 90.5 & 4.4 & 0.4 & 4.8 & 2.5 & 1.1 & 19.1 & 7.30 & 0.48 & 15.20 & 1.8 & 147 \\
\hline $\mathrm{CH} 19$ & 0.0 & 97.6 & 1.4 & 1.0 & 2.4 & 2.6 & 0.5 & 20.2 & 4.86 & 0.34 & 14.10 & 1.6 & 80 \\
\hline $\mathrm{CH} 20$ & 0.0 & 37.1 & 37.2 & 25.8 & 63.0 & 5.9 & 3.1 & 39.6 & 7.25 & 0.84 & 8.60 & 2.5 & - \\
\hline $\mathrm{CH} 21$ & - & - & - & - & - & - & - & 39.3 & 10.46 & 1.38 & 7.60 & 1.8 & 133 \\
\hline $\mathrm{CH} 22$ & 0.0 & 86.2 & 10.9 & 2.9 & 13.8 & 2.9 & 1.0 & 23.0 & 2.36 & 0.31 & 7.60 & 1.4 & 134 \\
\hline $\mathrm{CH} 23$ & 0.0 & 23.2 & 56.5 & 20.3 & 46.8 & 5.9 & 2.4 & 38.5 & 9.79 & 1.08 & 9.10 & 2.1 & 149 \\
\hline $\mathrm{CH} 25$ & 0.0 & 0.5 & 45.8 & 53.8 & 99.6 & 8.3 & 2.2 & 54.3 & 15.74 & 2.12 & 7.40 & 2.6 & 106 \\
\hline $\mathrm{CH} 26$ & 39.0 & 9.5 & 31.8 & 19.7 & 51.5 & 2.8 & 6.6 & 45.1 & 10.11 & 0.78 & 13.00 & 0.6 & - \\
\hline $\mathrm{CH} 27$ & 0.0 & 9.8 & 63.5 & 26.7 & 90.2 & 6.6 & 2.5 & 40.4 & 1.65 & 0.22 & 7.50 & 2.3 & - \\
\hline $\mathrm{CH} 28$ & 5.8 & 57.9 & 24.4 & 11.9 & 36.4 & 4.0 & 3.1 & 29.9 & 2.19 & 0.28 & 7.80 & 3.8 & - \\
\hline $\mathrm{CH} 29$ & 0.0 & 44.5 & 20.4 & 35.1 & 55.5 & 6.2 & 3.2 & 35.4 & 6.63 & 0.83 & 8.00 & 0.8 & 79 \\
\hline $\mathrm{CH} 30$ & 0.0 & 88.1 & 9.7 & 2.2 & 11.9 & 2.9 & 0.9 & 20.3 & 1.21 & 0.19 & 6.30 & 2.4 & - \\
\hline $\mathrm{CH} 31$ & 0.0 & 95.4 & 4.7 & 0.0 & 4.7 & 2.6 & 0.6 & 20.0 & 5.88 & 0.32 & 18.40 & 1.3 & 130 \\
\hline $\mathrm{CH} 32$ & 95.7 & 3.9 & 0.4 & 0.0 & 0.4 & -4.3 & 1.7 & 0.0 & - & - & - & - & - \\
\hline $\mathrm{CH} 33$ & 62.1 & 33.8 & 2.9 & 1.3 & 4.1 & -1.5 & 2.9 & 14.2 & 5.23 & 0.39 & 13.40 & - & - \\
\hline $\mathrm{CH} 34$ & 32.9 & 50.4 & 11.6 & 5.2 & 16.8 & -1.2 & 5.6 & 24.1 & 2.59 & 0.30 & 8.60 & 2.1 & 112 \\
\hline $\mathrm{CH} 35$ & 0.0 & 29.8 & 54.8 & 15.4 & 70.2 & 5.3 & 2.3 & 33.2 & 4.20 & 0.48 & 8.80 & 1.4 & 59 \\
\hline $\mathrm{CH} 36$ & 20.5 & 49.0 & 18.7 & 11.9 & 30.5 & 1.7 & 6.0 & 33.3 & 1.82 & 0.23 & 7.90 & 1.4 & - \\
\hline $\mathrm{CH} 37$ & 31.1 & 62.5 & 6.4 & 0.0 & 6.4 & 1.3 & 3.3 & 33.2 & 2.73 & 0.30 & 9.10 & 1.3 & 73 \\
\hline $\mathrm{CH} 38$ & 0.0 & 39.6 & 41.1 & 19.3 & 60.4 & 5.5 & 2.6 & 34.9 & 2.25 & 0.29 & 7.80 & 3.5 & - \\
\hline $\mathrm{CH} 39$ & 0.0 & 4.3 & 63.2 & 32.5 & 95.7 & 7.0 & 2.5 & 44.7 & 1.58 & 0.21 & 7.50 & 1.3 & - \\
\hline $\mathrm{CH} 40$ & 28.6 & 24.3 & 28.0 & 19.2 & 47.2 & 2.9 & 5.8 & 33.2 & 10.04 & 1.25 & 8.00 & 0.7 & - \\
\hline CHA1 & 64.5 & 23.0 & 7.9 & 4.6 & 12.5 & -5.4 & 7.9 & 29.2 & 4.48 & 0.55 & 8.20 & 0.9 & - \\
\hline $\mathrm{CH} 42$ & 0.0 & 31.8 & 47.3 & 21.0 & 68.2 & 5.6 & 2.9 & 36.8 & 2.40 & 0.40 & 6.00 & 0.7 & 136 \\
\hline $\mathrm{CH} 43$ & 60.3 & 19.7 & 14.2 & 5.8 & 20.0 & -0.4 & 4.0 & 20.4 & 8.89 & 1.01 & 8.00 & 2.5 & - \\
\hline $\mathrm{CH} 44$ & 0.0 & 47.9 & 43.0 & 9.1 & 52.1 & 4.6 & 1.6 & 31.5 & 7.73 & 0.99 & 7.80 & 3.9 & - \\
\hline $\mathrm{CH} 45$ & 0.0 & 26.7 & 59.4 & 13.8 & 73.3 & 5.3 & 1.9 & 38.3 & 9.46 & 1.18 & 8.00 & 3.8 & 185 \\
\hline $\mathrm{CH} 46$ & 0.0 & 14.2 & 63.2 & 22.7 & 85.8 & 6.2 & 2.5 & 42.1 & 2.29 & 0.28 & 8.20 & 0.6 & 221 \\
\hline $\mathrm{CH} 47$ & 0.0 & 12.8 & 60.9 & 26.3 & 87.2 & 6.5 & 2.6 & 45.8 & 11.79 & 1.55 & 7.60 & 0.8 & - \\
\hline
\end{tabular}


Appendix II. Station number, depth, number of taxa, abundance, biomass, Simpson domunance $(D)$ and Shannon diversity $\left(H^{\prime}\right)$ indices for benthic macrofauna collected at 37 stations

\begin{tabular}{|c|c|c|c|c|c|c|}
\hline Stn & Depth (m) & No. of taxa & Abundance (ind. $\mathrm{m}^{-2}$ ) & Biomass $\left(\mathrm{gC}^{-2}\right)$ & $D$ & $H^{\prime}$ \\
\hline $\mathrm{CH} 3$ & 51 & 61 & 838 & 7.5 & 0.07 & 3.27 \\
\hline CH4 & 42 & 68 & 1.592 & 13.7 & 0.19 & 2.57 \\
\hline $\mathrm{CH} 5$ & 19 & 74 & 3656 & 6.6 & 0.18 & 2.40 \\
\hline $\mathrm{CH} 6$ & 27 & 101 & 8472 & 5.6 & 0.22 & 2.52 \\
\hline $\mathrm{CH} 7$ & 31 & 1.23 & 7482 & 19.6 & 0.26 & 2.50 \\
\hline $\mathrm{CH} 8$ & 46 & 40 & 2508 & 13.2 & 0.65 & 1.07 \\
\hline $\mathrm{CH} 10$ & 47 & 79 & 2912 & 13.0 & 0.11 & 2.88 \\
\hline $\mathrm{CH} 1 \mathrm{H}$ & 32 & 87 & 1922 & 3.6 & 0.04 & 3.71 \\
\hline $\mathrm{CH} 12$ & 44 & 46 & 758 & 11.4 & 0.09 & 2.90 \\
\hline $\mathrm{CH} 13$ & 48 & 35 & 454 & 10.3 & 0.14 & 2.52 \\
\hline $\mathrm{CH} 14$ & 47 & 61 & 726 & 12.1 & 0.04 & 3.49 \\
\hline $\mathrm{CH} 15$ & 47 & 107 & 4392 & 11.2 & 0.19 & 2.73 \\
\hline $\mathrm{CH} 16$ & 43 & 143 & 31576 & 16.0 & 0.70 & 1.10 \\
\hline $\mathrm{CH} 17$ & 23 & 91 & 4998 & 6.6 & 0.22 & 2.61 \\
\hline $\mathrm{CH} 18$ & 18 & 29 & 462 & 3.2 & 0.19 & 2.35 \\
\hline $\mathrm{CH} 19$ & 30 & 43 & 1622 & 5.8 & 0.28 & 1.94 \\
\hline $\mathrm{CH} 21$ & 42 & 52 & 1146 & 11.8 & 0.06 & 3.30 \\
\hline $\mathrm{CH} 23$ & 42 & 52 & 616 & 9.6 & 0.06 & 3.30 \\
\hline $\mathrm{CH} 24$ & 43 & 54 & 1270 & 7.6 & 0.09 & 3.03 \\
\hline $\mathrm{CH} 25$ & 51 & 45 & 974 & 16.6 & 0.12 & 2.64 \\
\hline $\mathrm{CH} 26$ & 47 & 37 & 564 & 7.0 & 0.21 & 2.38 \\
\hline $\mathrm{CH} 27$ & 42 & 48 & 772 & 2.9 & 0.09 & 2.99 \\
\hline $\mathrm{CH} 28$ & 41 & 55 & 994 & 8.2 & 0.08 & 3.12 \\
\hline $\mathrm{CH} 29$ & 43 & 52 & 734 & 4.1 & 0.06 & 3.25 \\
\hline $\mathrm{CH} 30$ & 39 & 40 & 810 & 3.0 & 0.13 & 2.70 \\
\hline $\mathrm{CH} 31$ & 26 & 23 & 702 & 5.6 & 0.28 & 1.73 \\
\hline $\mathrm{CH} 33$ & 18 & 72 & 6988 & 3.2 & 0.44 & 1.65 \\
\hline $\mathrm{CH} 34$ & 32 & 53 & 2296 & 6.9 & 0.11 & 2.73 \\
\hline CH35 & 39 & 45 & 1328 & 9.7 & 0.08 & 2.89 \\
\hline $\mathrm{CH} 36$ & 44 & 45 & 1044 & 6.5 & 0.14 & 2.65 \\
\hline $\mathrm{CH} 37$ & 47 & 70 & 2566 & 7.2 & 0.19 & 2.58 \\
\hline $\mathrm{CH} 39$ & 48 & 31 & 1062 & 4.6 & 0.44 & 1.62 \\
\hline $\mathrm{CH} 40$ & 45 & 94 & 2014 & 11.5 & 0.04 & 3.72 \\
\hline $\mathrm{CH} 43$ & 23 & 37 & 3938 & 2.1 & 0.39 & 1.52 \\
\hline $\mathrm{CH} 44$ & 31 & 39 & 2320 & 6.8 & 0.13 & 2.56 \\
\hline $\mathrm{CH} 45$ & 45 & 35 & 828 & 1.0 & 0.12 & 2.69 \\
\hline $\mathrm{CH} 47$ & 50 & 28 & 632 & 4.3 & 0.11 & 2.54 \\
\hline
\end{tabular}

Acknowledgements. H.M.F. and A.S.N. were supported by the Minerals Management Service, Department of Interior, through an interagency agreement with the National Oceanic and Atmospheric Administration to them at the University of Alaska Fairbanks. T.E.W. was supported by ISHTAR (Grant No. DPP8605659) and ARCSS (Grant No. DPP9216130). Samples were collected on the NOAA Ship 'Oceanographer' and the Russian ship RV 'Khromov'. We thank the following Institute of Marine Science, University of Alaska Fairbanks, personnel: Dave Foster, Gail Gardner, Tama Rucker and John Smithhisler for shipboard sampling assistance; Dr M. Baskaran and Wieslaw Wajda for sediment analysis; Tama Rucker for laboratory analysis of biological samples; Chirk Chu and Arny Blanchard for data processing and programming; and Dr T Weingartner for examining sections of the paper concerning physical oceanographic data interpretations. Oxygen samples were analyzed by A. M. Seledtsov. We acknowledge the Arctic Institute of North America for permission to reprint Figs. $1 \& 2$. We thank Drs John Gray and Tom Pearson, and an anonymous reviewer for valuable comments which improved the manuscript. This is Institute of Marine Science Contribution No. 1007

\section{LITERATURE CITED}

Aagaard, K., Roach, A. T (1990). Arctic ocean-shelf exchange: measurements in Barrow Canyon. J geophys. Res. 95: 18163-18175

Arctic Ocean Science Board (1988). International Arctic Polynya Project (IAP ${ }^{2}$ ) (A Program of the Arctic Ocean Sciences Board). Univ, of Alaska, Fairbanks
Arctic Ocean Science Board (1989). International Arctic Polynya Project ( IAP $^{2}$ ) (A Program of the Arctic Ocean Sciences Board). Univ. of Alaska, Fairbanks

Barnes, P. W. (1972). Preliminary results of geological studies in the eastern central Chukchi Sea. U.S. Coast Guard Oceanogr. Rep. Ser. 50: 87-110

Barnes, P. W., Reimnitz, E. (1974). Sea ice as a geologic agent on the Beaufort Sea shelf of Alaska. In: Reed, J. C., Sater, J. E. (eds.) The coast and shelf of the Beaufort Sea. Arctic Institute of North America, Arlington, p. 301-353

Barnes, P. W., Schell, D. M., Reimnitz, E. (1984). The Alaskan Beaufort Sea: ecosystems and environments. Academic Press, Orlando

Boesch, D. F. (1973). Classification and community structure of macrobenthos of the Hampton Roads area, Virginia. Mar. Biol. 21: 226-244

Boesch, D. F. (1977). Application of numerical classification to ecological investigation of water pollution. EPA Ecol. Res. Ser. 600/3-77-033

Boesch, D. F., Rosenberg, R. (1981). Response to stress in marine benthic communities. In: Barrett, G. W., Rosenberg, R. (eds.) Stress effects on natural ecosystems. John Wiley and Sons, Ltd, New York, p. 179-200

Boswell, P. G. H. (1961). Muddy sediments. Heffer Co., Cambridge

Bray, J. R., Curtis, J. T (1957). An ordination of the upland forest communities of southern Wisconsin. Ecol. Monogr 27: $235-249$

Brenchley, G. A. (1981). Disturbance and community structure: an experimental study of bioturbation in marine softbottom environments. J mar. Res. 39: 767-790 
Burbank, D. C. (1974). Suspended sediment transport and deposition in Alaskan coastal waters. M.S. thesis, Univ. of Alaska, Fairbanks

Carey, A. G. (1991). Ecology of north American arctic continental shelf benthos: a review. Cont. Shelf Res. 11. 865-883

Carey, A. G. Jr, Ruff, R. E., Castillo, J. G., Dickinson, J J. (1974). Benthic ecology of the western Beaufort Sea continental margin: preliminary results. In: Reed, J. C., Sater, J. F. (eds.) The coast and shelf of the Beaufort Sea. Arctic Institute of North America, Arlington, p. 665-680

Carey, A. G. Jr, Boudrias, M. A., Kern, J. C., Ruff, R. E. (1984). Selected ecological studies on continental shelf benthos and sea ice fauna in the southwestern Beaufort Sea. In: Outer continental shelf environmental assessment program. Final report of principal investigators 23. U.S. Dept of Commerce, NOAA, Washington, DC, p. 1-164

Clarke, J. T., Moore, S. E., Ljungblad, D. K. (1987). Observations on gray whale (Eschrichtius robustus) utilization patterns in the northeastern Chukchi Sea, July-October 1982-86. 7th Biennial Conf. Biol. Mar. Mammals. The Society for Marine Mammalogy, Univerity of Miami, Miami, FL, p. 11 (Abstract)

Coachman, L. K., Aagaard, K., Tripp, R. B. (1975). Bering Strait: the regional physical oceanography. Univ. of Washington Press, Seattle

Coachman, L. K., Shigaev, V. V. (1992). The northern BeringChukchi Sea ecosystem: the physical basis. In: Nagel, P. A. (ed.) Results of the Third Joint US-USSR Bering and Chukchi Seas Expedition (BERPAC), Summer 1988. U.S. Fish and Wildlife Service, Washington, DC, p. 17-27

Codispoti, L. A., Richards, F. A. (1971). Oxygen supersaturation in the Chukchi and East Siberian Seas. Deep Sea Res. 18: $341-351$

Cooney, R. T., Coyle, K. O. (1982). Trophic implications of cross-shelf copepod distributions in the southeastern Bering Sea. Mar. Biol. 70: 187-196

Coull, B. C. (ed.) (1977). Ecology of marine benthos. Univ. of South Carolina Press, Columbia

Coyle, K. O., Highsmith, R. C. (1994). Benthic amphipod community in the northern Bering Sea: analysis of potential structuring mechanisms. Mar Ecol. Prog. Ser. 107: 233-244

Creutzberg, F., Wapenaar, P., Duineveld, G., Lopez, N. L. (1984). Distribution and density of the benthic fauna in the southern North Sea in relation to bottom characteristics and hydrographic conditions. Rapp. P.-v. Réun. Cons. int. Explor. Mer 183: 101-110

Davis, R. A., Thomson, D. H. (1984). Marine mammals. In: Truett, J. C. (ed.) The Barrow Arch environment and possible consequences of planned offshore oil and gas development. NOAA/OCSEAP, Anchorage, p. 47-79

Day, J. H., Field, J. G., Montgomery, M. P. (1971). The use of numerical methods to determine the distribution of the benthic fauna across the continental shelf off North Carolina. J. Anim. Ecol. 40: 93-123

Deming, J., Johnson, M., Smith, W. (1993). Northeast water polynya: Polar Sea cruise results. EOS Trans. Am. geophys. Union 74: 185 \& 195-196

Duggins, D. O., Simenstad, C. A., Estes, J. A. (1989). Magnification of secondary production by kelp detritus in coastal marine ecosystems. Science 245: 170-173

Dunbar, M. J. (1968). Ecological development in polar regions. Prentice-Hall, Englewood Cliffs

Dunbar, M. J. (1981). Physical causes and biological significance of polynyas and other open water in sea ice. In: Stirling, 1., Cleator, H. (eds.) Polynyas in the Canadian
Arctic. Canadian Wildlife Service, Occas. Paper No. 45 , p. $29-43$

Dunton, K. H., Saupe, S. M., Golikov, A. N., Schell, D. M., Schonberg, S. V. (1989). Trophic relationships and isotopic gradients among arctic and subarctic marine fauna. Mar. Ecol. Prog. Ser. 56: 89-97

Fay, F. H. (1982) Ecology and biology of the Pacific walrus, Odobenus rosmarus divergens llliger. North America Fauna, 74, U.S. Dept Interior, Fish and Wildlife Service, Washington, DC

Feder, H. M., Day, R. H., Jewett, S. C., McCumby, K., McGee, S., Schonberg, S. V. (1985). Infauna of the northeastern Bering and southeastern Chukchi Seas. In: Outer continental shelf environmental assessment program. Final reports of principal investigators 32 . U.S. Dept of Commerce, NOAA, Washington, DC, p. 1-120

Feder, H. M., Foster, N. R., Jewett, S. C., Weingartner, T. J., Baxter, R. (1994). Mollusks in the northeastern Chukchi Sea. Arctic 47: 145-163

Feder, H. M., Naidu, A. S., Baskaran, M., Frost, K., Hameedi, M. J., Jewett, S. C., Johnson, W. R., Raymond, J., Schell, D. (1990). Bering Strait-Hope Basin: habitat utilization and ecological characterization. Final Report to NOAA/OAD Alaska Office, Anchorage, Alaska. Institute of Marine Science, Univ. of Alaska Fairbanks, Fairbanks, p. 1-465 (also available as IMS Tech. Rep. 92-2 which can be obtained from the Institute of Marine Science, Univ. of Alaska Fairbanks, Fairbanks, AL 99775-1080)

Feder, H. M., Naidu, A. S., Hameedi, M. J., Jewett, S. C., Johnson, W. R. (1989). The Chukchi Sea continental shelf: benthos-environmental interactions. OCSEAP Final Rep. 68. U.S. Dept Commerce, NOAA, Washington, DC, p. 25-311 (also available as IMS Tech. Rep 92-1 which can be obtained from the Institute of Marine Science, Univ. of Alaska Fairbanks, Fairbanks, AL 99775-7220)

Feder, H. M., Schamel, D. (1976). Shallow-water benthic fauna of Prudhoe Bay. In: Hood, D. W., Burrell, D. C. (eds.) Assessment of the Arctic marine environment: selected topics. Occas. Publ. No. 4. Inst. Mar. Sci., Univ. of Alaska, Fairbanks, p. 329-359

Filatova, Z. A. (1957). General review of the bivalve mollusks of the northern seas of the USSR. In: Transactions of the Institute of Oceanology, Vol. XX, Marine biology (ed. Nikitin, B. N.) The American Institute of Biological Sciences, Washington, DC, p. 1-44

Flint, R. W. (1981). Gulf of Mexico outer continental shelf benthos: macrofaunal-environmental relationships. Biol. Oceanogr. 1. 135-155

Folk, R. L. (1980). Petrology of sedimentary rocks. Hemphill Publishing Co., Austin

Franz, D. (1976). Benthic molluscan assemblages in relation to sediment gradients in northeastern Long Island Sound, Connecticut. Malacologia 15: 377-399

Gower, J. C. (1967). Multivariate analysis and multidimensional geometry. Statistician 17: 13-28

Gower, J. C. (1969). A survey of numerical methods useful in taxonomy. Acarologia 11:357-375

Grantz, A., Dinter, D. A., Hill, E. R., Hunter, R. E., May, S. D., McMullin, R. H., Phillips, R. L. (1982). Geologic framework, hydrocarbon potential, and environmental conditions for exploration and development of proposed oil and gas lease sale 85 in the central Chukchi Sea. U.S. Geol. Surv. Open File Rep. 82-1053

Grebmeier, J. M., Barry, J. P. (1991). The influence of oceanographic processes on pelagic-benthic coupling in polar regions. J. mar. Syst. 2: 495-518

Grebmeier, J. M., Feder, H. M., McRoy, C. P. (1989). Pelagic- 
benthic coupling in the northern Bering and southern Chukchi Seas. II. Benthic community structure. Mar. Ecol. Prog. Ser. 51: 253-268

Grebmeier, J. M., McRoy, C. P., Feder, H. M. (1988). Pelagicbenthic coupling on the shelf of the northern Bering and Chukchi Seas. I. Food supply source and benthic biomass. Mar. Ecol. Prog. Ser. 48: 57-64

Highsmith, R. C. (1982). Induced settlement and metamorphosis of sand dollar (Dendraster excentricus) larvae in predator-free sites: adult sand dollar beds. Ecology 63: $329-337$

Highsmith, R. C., Coyle, K. O. (1992). Productivity of arctic amphipods relative to gray whale energy requirements. Mar. Ecol. Prog. Ser. 83: 141-150

Hill, E. R., Grantz, A., May, S. D., Smith, M. (1984). Bathymetric map of the Chukchi Sea. Map I-1182-D, Dept of Interior, U.S. Geol. Survey, Menlo Park

Hoberg, M. K., Feder, H. M., Jewett, S. C. (1980). Some aspects of the biology of the parasitic gastropod, Asterophila japonica Randall and Heath (Prosobranchia: Melanellidae), from southeastern Chukchi Sea and northeastern Bering Sea, Alaska. Ophelia 19: 73-77

Hoberg, M. K., McGee, S. G., Feder, H. M. (1982). Polychaetes and amphipods as commensals with pagurids from the Alaska shelf. Ophelia 21: 167-179

Ingham, M. C., Rutland, B. A., Barnes, P. W., Watson, G. E., Divoky, G. J., Naidu, A. S., Sharma, G. D., Wing, B. L., Quast, J. C. (1972). WEBSEC-70, an ecological survey in the eastern Chukchi Sea. U.S.C.G. Oceanographic Rep. 50 (CG 373-50). U.S. Coast Guard Oceanogr. Unit, Washington, DC, p. $1-206$

Jandel (1992). SigmaStat statistical software for working scientists. Jandel, Inc., San Rafael, CA

Jewett, S. C. (1988a). Infaunal invertebrate biomass, Section 2.5. In: Bering, Chukchi, and Beaufort Seas strategic assessment: data atlas. U.S. Dept Commerce, NOAA, Ocean Assessment Div., Washington, DC

Jewett, S. C. (1988b). Epifaunal invertebrate biomass, Section 2.4. In: Bering, Chukchi, and Beaufort Seas strategic assessment: data atlas. U.S. Dept Commerce, NOAA, Ocean Assessment Div., Washington, DC

Johnson, W. R. (1989). Current response to wind in the Chukchi Sea: a regional upwelling event. J. geophys. Res 94: $2057-2064$

Jones, G., Candy, S. (1981). Effect of dredging on the macrobenthic infauna of Botany Bay. Aust. J. mar. Freshwat. Res. 32: 379-399

Jumars, P. A., Fauchald, K. (1977). Between-community contrasts in successful polychaete feeding strategies. In Coull, B. C. (ed.) Ecology of marine benthos. Univ of South Carolina Press, Columbia, p. 1-20

Klaus, A. D., Oliver, J. S., Kvitek, R. G. (1990). The effects of gray whale, walrus, and ice gouging disturbance on benthic communities in the Bering Sea and Chukchi Sea, Alaska. Natl. Geograph. Res. 6: 470-484

Korsak, M. N. (1992). Primary production of organic matter In: Nagel, P. A. (ed.) Results of the Third Joint US-USSR Bering \& Chukchi Seas Expedition (BERPAC). Summer 1988. U.S. Fish and Wildlife Service, Washington, DC, p. $215-218$

Long, B., Lewis, J. B. (1987). Distribution and community structure of the benthic fauna of the Gulf of St. Lawrence described by numerical methods of classification and ordination. Mar. Biol. 95: 93-101

MacGinitie, G. E. (1955). Distribution and ecology of the marine invertebrates of Point Barrow, Alaska. Smithsonian misc. Collect. 128: 1-201
MacGinitie, N. \{1959\}. Marine mollusca of Point Barrow, Alaska. Proc. U.S. natl. Mus. 109: 59-208

McCave, 1. N. (1976). The benthic boundary layer. Plenum Press, New York

McRoy, C. P., Goering, J. J. (1974). The influence of ice on primary productivity of the Bering Sea. In: Hood, D. W. Kelley, E. J. (eds.) The oceanography of the Bering Sea. Institute of Marine Science, Univ. of Alaska, Fairbanks

Mann, K. H. (1982). Ecology of coastal waters: a systems approach. Studies in ecology, Vol. 8. Univ. Calif. Press, Los Angeles

Margalef, R. (1958). Information theory in ecology. Gen. Syst 3: $36-71$

Massom, R. A. (1988). The biological significance of open water within the sea ice covers of the polar regions. Endeavour 12: 21-26

Moore, S. E., Clarke, J. T. (1986). A comparison of gray whale (Eschrichtius robustus) and bowhead whale (Balaena mysticetus) distribution, abundance, habitat preference and behavior in the northeastern Chukchi Sea, 1982-84. Rep. Int. Whal Comm. 36: 273-279

Moore, S. E., Clarke, J. T. (1992). Distribution, abundance and behavior of endangered whales in the Alaskan Chukchi and western Beaufort Seas: with a review 1982-91. OCS Study MMS-92-0029. Final report prepared for the U.S Minerals Management Service, Alaska OCS Region. SAIC, Maritime Services Division, San Diego

Musina, A. A., Balysheva, E. V. (1960). Hydrochemical features of arctic seas. Khim. Morya. 10:61-68 (in Russian)

Naidu, A. S. (1985). Organic carbon, nitrogen, and $\mathrm{C} / \mathrm{N}$ ratios of deltaic sediments, North Arctic Alaska. Mitt. Geol. Paläont. Inst. Univ. Hamburg, SCOPE/UNEP. Sonderbd 58: $311-321$

Naidu, A. S. (1988). Marine surficial sediments, Section 1.2. In: Bering, Chukchi and Beaufort Seas, coastal and ocean zones strategic assessment: data atlas. NOAA/SAB, Dept Commerce, Rockville

Naidu, A. S., Hood, D. W. (1972). Chemical composition of bottom sediments of the Beaufort Sea, Arctic Ocean. Proc. 24th int. Geol. Congr. Harpell's Press Cooperative, Gardenvale, Quebec, Section 10, p. 307-317

Nemoto, T., Harrison, G. (1981). High latitude ecosystems. In: Longhurst, A. R. (ed.) Analysis of marine ecosystems Academic Press, New York, p. 95-126

Nerini, M. K. (1984). A review of gray whale (Eschrichtius robustus) feeding ecology. In: Jones, M. L., Swartz, S. L. Leatherwood, J. S. (eds.). The gray whale. Academic Press, San Francisco, p. 423-450

Odum, E. P. (1975). Ecology. Holt, Rinehart and Winston, New York

Oliver, J. S., Slattery, P. N. (1985). Destruction and opportunity on the sea floor: effects of gray whale feeding. Ecology 66: $1965-1975$

Parrish, D. M. (1987). An estimate of annual primary production in the Alaska Arctic Ocean. M.S. thesis, Univ. of Alaska, Fairbanks

Phillips, R. L. (1987). Summary of geology, processes, and potential geohazards in the northeastern Chukchi Sea. In: Hale, D. A. (ed.) Chukchi Sea: information update. NOAA/NOS Service, Ocean Assessment Div., Anchorage, p. 21-31

Phillips, R. L., Colgan, M. W. (1987). Sea-floor feeding traces of gray whales and walrus in the northeast Chukchi Sea. In: Galloway, J. P., Hamilton, T. D. (eds.) Geologic studies in Alaska by the U.S. Geological Survey during 1987. U.S. Geol. Survey Circular 1016, p. 183-186

Phillips, R. L., Reiss, T. E. (1985a). Nearshore marine geo- 
logical investigations, Icy Cape to Wainwright, northeast Chukchi Sea. U.S. Geol. Survey Open File Rep. 84-828, USGS, Menlo Park, p. 1-27

Phillips, R. L., Reiss, T. E. (1985b). Nearshore marine geologic investigations, Point Barrow to Skull Cliff, Northeast Chukchi Sea. Final report submitted to NOAA-NOS, Anchorage, p. 157-181 (available from U.S. Geological Survey, Menlo Park)

Piepenburg, D. (1988). On the composition of the benthic fauna of the western Fram strait. Ber. Polarforsch. 52: 1-118

Poiner, I. R., Kennedy, R. (1984). Complex patterns of change in the macrobenthos of a large sandbank following dredging. Mar. Biol. 78: 335-352

Postma, H., Zijlstra, J. J. (1988). Continental shelves. Ecosystems of the world. Elsevier Science Publishers, Amsterdam

Probert, P. K., Wilson, J. B. (1984). Continental shelf benthos off Otago Peninsula, New Zealand. Estuar. coast. Shelf Sci. 19: 373-391

Rhoads, D. C. (1974). Organism-sediment relations on the muddy sea floor. Oceanogr. mar. Biol. 12: 263-300

Robie, W. S., McRoy, C. P., Springer, A. M. (1992). Phytoplankton biomass distribution in the northern Bering Sea and southern Chukchi Sea. In: Nagel, P. A. (ed.) Results of the Third Joint US-USSR Bering \& Chukchi Seas Expedition (BERPAC), Summer 1988. U.S. Fish and Wildlife Service, Washington, DC, p. 123-127

Sanders, H. L. (1960). Benthic studies in Buzzards Bay. IIJ. The structure of the soft-bottom community. Limnol. Oceanogr. 5: 138-153

Shannon, C. E., Weaver, W. (1963). The mathematical theory of communication. Univ. of Illinois Press, Urbana

Shin, P. K. (1982). Multiple discriminant analysis of macrobenthic infaunal assemblages. J. exp. mar. Biol. Ecol. 59: $39-50$

Simpson, E. H. (1949). The measurement of diversity. Nature 163: 688

Smith, A. L. (1981). Comparison of macrofaunal invertebrates in sand dollar (Dendraster excentricus) beds and in adjacent areas free of sand dollars. Mar. Biol. 65: 191-198

Smith, S. D., Muench, R. D., Pease, C. H. (1990). Polynyas and leads: an overview of physical processes and environment. J. geophys. Res. 95: 9461-9479

Sparks, A. K., Pereyra, W T. (1966). Benthic invertebrates of the southeastern Chukchi Sea. In: Wilimovsky, N. J., Wolfe, J. N. (eds.) Environment of the Cape Thompson region, Alaska. U.S. Atomic Energy Commission, Oak Ridge, p. 817-838

Spaulding, M., Isaji, T., Mendelsohn, D., Turner, A. C. (1987). Numerical simulation in wind-driven flow through the Bering Strait. J. phys. Oceanogr. 17: 1799-1816

Springer, A. M., McRoy, C. P., Turco, K. R. (1989). The paradox of pelagic food webs in the northern Bering Sea. II. Zooplankton communities. Cont. Shelf. Res. 9: 359-386

Stephenson, W., Williams, W. T. (1971). A study of the benthos of soft bottoms. Sek Harbour, New Guinea, using numerical analysis. Aust. J. mar. Freshwat. Res. 22: 11-34

Stewart, P. L., Pocklington, P., Cunjak, R. A. (1985). Distribution, abundance and diversity of benthic macroinvertebrates on the Canadian continental shelf and slope of southern Davis Strait and Ungava Bay. Arctic 38: 281-291

Stoker, S. W. (1978). Benthic invertebrate macrofauna on the eastern continental shelf of the Bering and Chukchi seas. Ph.D. dissertation, Univ. Alaska, Fairbanks

Stoker, S. W. (1981). Benthic invertebrate macrofauna of the eastern Bering/Chukchi continental shelf. In: Hood, D. W., Calder, J. A. (eds.) The eastern Bering Sea Shelf: aceano- graphy and resources, Vol. 2. NOAA Office of Marine Pollution Assessment. Univ. Washington Press, Seattle, p. $1069-1090$

Stringer, W. J., Groves, J. E. (1991). Location and areal extent of polynyas in the Bering and Chukchi Seas. Arctic 44 (Suppl. 1): 164-171

Subba Rao, D. V., Platt, T. (1984). Primary production of arctic waters. Polar Biol. 3: 191-201

Tenore, K. R., Coull, B. C. (eds.) (1980). Marine benthic dynamics. Univ. of South Carolina Press, Columbia

Thistle, D. (1981). Natural physical disturbances and communities of marine soft bottoms. Mar. Ecol. Prog. Ser. 6: 223-228

Thomson, D. H. (1982). Marine benthos in the eastern Canadian high arctic: multivariate analyses of standing crop and community structure. Arctic 35: 61-74

Thorson, G. (1957). Bottom communities (sublittoral or shallow shelf). In: Hedgpeth, J. W. (ed.) Treatise on marine ecology and paleoecology, Vol. 1, Ecology, Memoir 67. Geological Society of America, New York, p. 461-634

Toimil, L. J. (1978). Ice gouge microrelief on the floor of the eastern Chukchi Sea, Alaska: a reconnaissance survey. U.S. Geol. Survey Open-file Rep. p. 1-94

Truett, J. C. (1984). The Barrow Arch environment and possible consequences of planned offshore oil and gas development. NOAA/OCSEAP, Anchorage

Walsh, J. J. (1989). Arctic carbon sinks: present and future. Global Biogeochem. Cycles 3: 393-411

Walsh, J. J., McRoy, C. P. (1986). Ecosystem analysis in the southeastern Bering Sea. Cont. Shelf Res. 5: 259-288

Walsh, J. J., McRoy, C. P., Blackburn, T. H., Coachman, L. W., Goering, J. J., Henriksen, K., Andersen, P., Nihoul, J. J., Parker, P. L., Springer, A. M., Tripp, R. B., Whitledge, T. E., Wirick, C. D. (1989a). The role of Bering Strait in the carbon/nitrogen fluxes of polar marine ecosystems. In: Rey, L., Alexander, V. (eds.) Marine living systems of the far north. E. J. Brill, Leiden, p. 90-120

Walsh, J. J., McRay, C. P., Coachman, L. W., Goering, J. J., Nihoul, J. J., Whitledge, T. E., Blackburn, T H., Parker, P. L., Wirick, C. D., Shuert, P. G., Grebmeier, J. M., Springer, A. M., Tripp, R. D., Hansell, D. A., Djenidi, S., Deleersnijder, E., Henriksen, K., Lund, B. A., Anderson, P., Muller-Karger, F. E., Dean, K. (1989b). Carbon and nitrogen cycling within the Bering/Chukchi Seas: source regions for organic matter affecting $\mathrm{AOU}$ demands of the Arctic Ocean. Prog. Oceanogr, 22: 277-359

Webb, J. E. (1976). Organism-sediment relationships. In: McCave, I. N. (ed.) The benthic boundary layer. Plenum Press, New York

Weingartner, T J (1993). The physical oceanography of the northeast Chukchi Sea. In: Alaska OCS Region Fifth Information Transfer Meeting. Conference Proceedings. OCS Study MMS 93-0043. U.S. Dept Int. Min. Management Service, OCS Region, Anchorage, p. 263-270

Weston, D. P. (1988). Macrobenthos-sediment relationships on the continental shelf off Cape Hatteras, North Carolina. Cont. Shelf Res. 8: 267-286

Whitledge, T. E., Gorelkin, M. I., Chernyak, S. M. (1992). Biogenic nutrient content. In: Nagel, P. A. (ed.) Results of the Third Joint US-USSR Bering and Chukchi Seas Expedition (BERPAC), Summer 1988. U.S. Fish and Wildlife Service, Washington, DC, p. 243-251

Whitledge, T E., Malloy, S., Patton, C., Wirick, C. D. (1981). Automated nutrient analyses in seawater. Brookhaven National Laboratory Tech. Rep. BNL 51398, p. 1-216

Whitledge, T E., Reeburgh, W. S., Walsh, J. J. (1986). Seasonal inorganic nitrogen distribution and dynamics in the southeastern Bering Sea. Cont. Shelf Res. 5: 109-132 
Whitledge, T. E., Salo, S. (1991). Biogeochemical cycling with respect to the nutrient-water mass environment on the Chukchi Sea shelf. EOS 72 (AGU 1991 Fall Meeting Suppl.): 236 (abstract)

Wilkinson, L. (1990). SYSTAT: the system for statisticians. Systat, Inc., Evanston, IL

Wiseman, W. J., Rouse, L. J. Jr (1980). A coastal jet in the Chukchi Sea. Arctic 33: 21-29

Woodworth-Lynas, C. M. T., Josenhans, H. W., Barrie, J. V. Lewis, C. F. M., Parrott, D. R. (1991). The physical

This article was presented by J. S. Gray (Senior Editorial Advisor), Oslo, Norway processes of seabed disturbance during iceberg grounding and scouring. Cont. Shelf Res. 11: 939-961

Young, D. K., Rhoads, D. C. (1971). Animal-sediment relations in Cape Cod Bay, Mass. I. A transect study. Mar. Biol. 11: $242-254$

Zeeman, S. I. (1992). The importance of primary production and $\mathrm{CO}_{2}$. In: Nagel, P. A. (ed.) Results of the Third Joint US-USSR Bering \& Chukchi Seas Expedition (BERPAC), Summer 1988. U.S. Fish and Wildlife Service, Washington, DC, p. 218-224

Manuscript first received: April 20,1993

Revised version accepted: March 21, 1994 